\title{
The sensitivity of $\mathrm{CO}$ and aerosol transport to the temporal and vertical distribution of North American boreal fire emissions
}

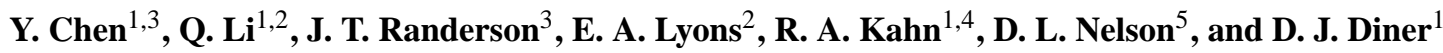 \\ ${ }^{1}$ Jet Propulsion Laboratory, California Institute of Technology, Pasadena, CA, USA \\ ${ }^{2}$ University of California, Los Angeles, CA, USA \\ ${ }^{3}$ University of California, Irvine, CA, USA \\ ${ }^{4}$ NASA Goddard Space Flight Center, Greenbelt, MD, USA \\ ${ }^{5}$ Raytheon Company, Pasadena, CA, USA
}

Received: 20 February 2009 - Published in Atmos. Chem. Phys. Discuss.: 15 May 2009

Revised: 8 August 2009 - Accepted: 21 August 2009 - Published: 10 September 2009

\begin{abstract}
Forest fires in Alaska and western Canada represent important sources of aerosols and trace gases in North America. Among the largest uncertainties when modeling forest fire effects are the timing and injection height of biomass burning emissions. Here we simulate $\mathrm{CO}$ and aerosols over North America during the 2004 fire season, using the GEOS-Chem chemical transport model. We apply different temporal distributions and injection height profiles to the biomass burning emissions, and compare model results with satellite-, aircraft-, and ground-based measurements. We find that averaged over the fire season, the use of finer temporal resolved biomass burning emissions usually decreases $\mathrm{CO}$ and aerosol concentrations near the fire source region, and often enhances long-range transport. Among the individual temporal constraints, switching from monthly to 8-day time intervals for emissions has the largest effect on $\mathrm{CO}$ and aerosol distributions, and shows better agreement with measured day-to-day variability. Injection height substantially modifies the surface concentrations and vertical profiles of pollutants near the source region. Compared with $\mathrm{CO}$, the simulation of black carbon aerosol is more sensitive to the temporal and injection height distribution of emissions. The use of MISR-derived injection heights improves agreement with surface aerosol measurements near the fire source. Our results indicate that the discrepancies between model simulations and MOPITT CO measurements near the Hudson Bay can not be attributed solely to the representation
\end{abstract}

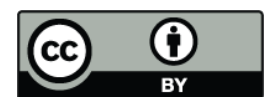

Correspondence to: Y. Chen (yang.chen@uci.edu) of injection height within the model. Frequent occurrence of strong convection in North America during summer tends to limit the influence of injection height parameterizations of fire emissions in Alaska and western Canada with respect to $\mathrm{CO}$ and aerosol distributions over eastern North America.

\section{Introduction}

Biomass burning is a substantial source of pollutants in the atmosphere (Andreae and Merlet, 2001). Incomplete combustion from fires produces large amounts of aerosols and trace gases, which play an important role in atmospheric chemistry and the radiation balance of the Earth-atmosphere system. Smoke from biomass burning consists of inorganic and organic aerosols including sulfates, nitrates, black carbon (BC), and organic carbon (OC). These tiny aerosols scatter incoming solar radiation directly or indirectly, leading to the cooling of Earth's surface and the atmosphere (Forster et al., 2007). The light-absorbing aerosol components (primarily BC) warm the atmosphere, counteracting cooling caused by light-scattering particles (Bond and Bergstrom, 2005). Deposition of BC on snow is shown to reduce the surface albedo and affect the climate in the Arctic (Hansen and Nazarenko, 2004; Stohl et al., 2006; Flanner et al., 2007; Stone et al., 2008). It is estimated that global mean direct radiative forcing for biomass burning aerosols is $+0.03 \pm 0.12 \mathrm{Wm}^{-2}$ (Forster et al., 2007). In addition to aerosols, large quantities of carbon monoxide (CO), nitrogen oxides $\left(\mathrm{NO}_{\mathrm{x}}\right)$ and non-methane hydrocarbons (NMHC) are also released to the atmosphere by biomass burning. These

Published by Copernicus Publications on behalf of the European Geosciences Union. 
species are major precursors to the photochemical production of tropospheric ozone (Goode et al., 2000) and thus have a large impact on atmospheric chemistry and air quality.

The biomass burning aerosols and trace gases are subject to long-range transport, with a potential to degrade the air quality thousand kilometers downwind. For instance, several studies have linked enhanced surface level pollutants in eastern and southeastern United States (e.g. Wotawa and Trainer, 2000; Colarco et al., 2004) and Europe (e.g. Forster et al., 2001) with North American boreal forest fires. A useful tool to investigate the effect of forest fires on atmospheric chemistry is global Chemical Transport Model (CTM), which tracks the transport of pollutants by relating the distributions of aerosols and trace gases to the biomass burning emissions from forest fires. Because the composition and distribution of smoke is highly variable, modeling forest fire effects requires spatially and temporally detailed estimates of biomass burning emissions (Kasischke et al., 2005).

The temporal variability and vertical distribution of biomass burning emissions, however, are not fully represented in most current CTMs. For example, emissions of trace gases and aerosols from biomass burning are typically prescribed on a monthly basis in most global CTMs. While this relatively low temporal resolution may be adequate for investigating the annual mean or seasonal variability of fire impacts, it may underestimate day-to-day fluctuations of pollutants particularly during severe pollution events. In addition, fire emissions are traditionally considered to be emitted near the surface and quickly mixed throughout the planetary boundary layer (PBL). Therefore, in most models, biomass burning emissions are initially distributed within the PBL only. Observations have shown that boreal forest fire emissions of aerosols and trace gases can rise above the PBL when sufficient buoyancy triggered by fire energy is available (Fromm et al., 2005; Kahn et al., 2007). Aerosols and trace gases generally have longer lifetimes in the free troposphere and therefore can travel further if the emissions are above the PBL. Some recent modeling studies have allowed for injection of biomass burning emissions above the PBL in CTM simulations (e.g. Matichuk et al., 2007; Turquety et al., 2007; Textor et al., 2007). However, the injection heights used in these simulations lack strong observational support. The impact of biomass burning emission temporal variability and injection height on the transport of aerosols and trace gases has not yet been well quantified.

In this study, we investigate the sensitivity of $\mathrm{CO}$ and aerosol transport to temporal and vertical distribution of biomass burning emissions. $\mathrm{CO}$ is an ideal tracer to study the transport of biomass burning emissions, due to its relatively long lifetime in the troposphere, $1-3$ months, and relatively simple chemistry. We conduct a series of simulations of CO and aerosols using the GEOS-Chem global CTM (Bey et al., 2001). Biomass burning emissions in the model are from the Global Fire Emission Database version 2 (GFEDv2) developed by van der Werf et al. (2006). This time series of emissions is available with both monthly and 8-day time steps. We use additional climate and satellite observations to distribute the 8-day emissions on daily and 3-hourly time intervals. One goal of this study is to determine the relative importance of the temporal constraints of emissions, using the monthly, 8-day, daily, and 3-hourly emissions time series as different tracers. Additionally, we investigate the sensitivity of transport to the parameterization of injection height. We conduct simulations in which emissions were distributed within the PBL, throughout the troposphere, and with vertical distributions derived from satellite-observed smoke plume injection heights. Our second goal is to better understand how different implementations of smoke injection may affect the spatial distribution and temporal variability of biomass burning pollutants.

Forest fire activity in North American boreal forests has increased in recent decades (Kasischke and Turetsky, 2006; Gillett et al., 2004), with higher air temperatures implicated as a contributing factor (Duffy et al., 2005). In this study, we focus on extensive burning of boreal forests in Alaska and western Canada during the summer of 2004. According to the National Interagency Fire Center (NIFC, http://iys.cidi.org/wildfire/), forest fires during the summer 2004 burned over 2.6 million hectares across Alaska. This burned area is well above the 10-year average $(\sim 0.3$ million hectares). Extensive fire activity also occurred in the Yukon Territory of Canada, where over 1.5 million hectares burned in summer 2004 (Canadian Interagency Forest Fire Centre, CIFFC, http://www.ciffc.ca/). Several different data streams during this period make it possible to track the longrange transport of the Alaskan and west Canadian forest fire emissions (e.g. Duck et al., 2007; Pfister et al., 2008; Real et al., 2007; Cook et al., 2007; Turquety et al., 2007). In this study, we evaluate model results with independent datasets collected from the DC-8 aircraft during the INtercontinental chemical Transport EXperiment - North America (INTEXNA) (Singh et al., 2006), retrieved by the Measurement of Pollution in the Troposphere (MOPITT) instrument aboard the NASA Terra satellite (Drummond et al., 1996; Deeter et al., 2003), measured in the EPA Interagency Monitoring of PROtected Visual Experiments (IMPROVE) program (Chow and Watson, 2002), and recorded by ground-based NASA Aerosol Robotic Network (AERONET) (Holben et al., 1998). These satellite-, aircraft-, and ground-based observations provide $\mathrm{CO}$ and aerosol data on multiple temporal and spatial scales, which helps interpret model results and allows us to suggest possible strategies for improving the atmospheric model.

The paper has the following organization. Section 2 describes the GEOS-Chem model. We then introduce different temporal constraints on biomass burning emissions in Sect. 3. Several ways of modeling biomass burning emission injection height are presented in Sect. 4. Various model simulations and the observations used for model evaluation are discussed in Sect. 5. In Sect. 6, we show the results of the 
different simulations, and compare them with atmospheric observations. We discuss the significance of improving emission temporal and vertical distribution for the simulation of biomass burning pollutants in Sect. 7. Finally, a summary is provided in Sect. 8.

\section{GEOS-Chem description}

GEOS-Chem is a global three-dimensional CTM (Bey et al., 2001) driven by assimilated meteorological observations from the Goddard Earth Observing System (GEOS) of the NASA Global Modeling and Assimilation Office (GMAO). We use here version 7-04-10 of the model (http://acmg.seas. harvard.edu/geos/) driven by GEOS-4 meteorological fields with 6-h temporal resolution (3-h for surface variables and mixing depths), $2^{\circ}$ (latitude) $\times 2.5^{\circ}$ (longitude) horizontal resolution, and 30 vertical layers between the surface and $0.01 \mathrm{hPa}$. The lowest model levels are centered at approximately $170,360,720,1300$, and $2100 \mathrm{~m}$ above the local surface.

The GEOS-Chem model includes a detailed description of tropospheric $\mathrm{O}_{3}-\mathrm{NO}_{\mathrm{x}}$-hydrocarbon chemistry. Gas phase chemical reaction rates and photolysis cross sections are taken from Sander et al. (2000). Photolysis frequencies are computed using the Fast-J algorithm (Wild et al., 2000). Advection is computed with a flux-form semi-Lagrangian method (Lin and Rood, 1996). The moist physics package includes the deep convection scheme of Zhang and McFarlane (1995) and the shallow convection scheme of Hack (1994).

In this study we applied the GEOS-Chem model for COonly and aerosol simulations. Emission sources of $\mathrm{CO}$ and carbonaceous aerosols include fossil fuel combustion, biomass burning, and biofuel burning. Emissions of other aerosols and aerosol precursors are as described in Park et al. (2004). CO loss is calculated using archived monthly mean $\mathrm{OH}$ concentration fields from a full-chemistry simulation (Hudman et al., 2004). Aerosols are assumed to be externally mixed. Eighty percent of BC and 50\% of OC emitted from biomass burning are assumed to be hydrophobic and hydrophobic aerosols become hydrophilic with an e-folding time of 1.2 days (Cooke et al., 1999). The dry deposition rates are calculated based on Wesley (1989). Soluble gases and aerosols are removed by scavenging in convective updrafts (Jacob et al., 2000) as well as rainout and washout by stratiform and convective anvil precipitation (Balkanski et al., 1993; Liu et al., 2001). A detailed description of the model has been reported by Bey et al. (2001) with updates by Park et al. (2004) and Hudman et al. (2007).

In the standard version (7-04-10) of GEOS-Chem, biomass burning emissions are from a climatological inventory with a monthly temporal resolution (Duncan et al., 2003). Here we use the GFEDv2 inventory that resolves the interannual variability of biomass burning emissions (van der
Werf et al., 2006). The original GFEDv2 inventory has a spatial resolution of $1^{\circ}$ (latitude) $\times 1^{\circ}$ (longitude) and a monthly temporal resolution. We re-sampled the emissions to $2^{\circ}$ (latitude) $\times 2.5^{\circ}$ (longitude) grids for use in our GEOS-Chem simulations.

GFEDv2 was derived using satellite observations including active fire counts and burned areas in conjunction with a biogeochemical model. Carbon emissions were calculated as the product of burned area, fuel loads and combustion completeness. Burned area was derived using active fire and 500-m burned area datasets from the Moderate Resolution Imaging Spectroradiometer (MODIS) as described by Giglio et al. (2006). Giglio et al. (2006) showed that the predicted burned area for Canada and the United States has a strong correlation with estimates compiled by Canadian Interagency Forest Fire Centre (CIFFC) and National Interagency Fire Center (NIFC). However, the burned area estimated as such has low biases amount to 17\% in Alaska and 30\% in Canada (Giglio et al., 2006), which will lead to low biases in the resulting emission estimates. In this study, we scaled the original GFEDv2 emissions by a factor of 1.2 over Alaska and 1.4 over Canada to account for the aforementioned low biases. The fuel loads, including organic soil layer and peatland fuels, were estimated based on the Carnegie-Ames-StanfordApproach (CASA) biogeochemical model (van der Werf et al., 2003). Combustion completeness was allowed to vary among fuel types and from month to month (van der Werf et al., 2006). Emission factors for extratropical forests from Andreae and Merlet (2001) were used to scale trace gas and aerosol emissions from carbon emissions. The resulting total boreal forest fire $\mathrm{CO}$ emissions in North America $\left(180^{\circ}-60^{\circ} \mathrm{W} ; 30^{\circ}-80^{\circ} \mathrm{N}\right)$ were $32 \mathrm{Tg}$ for June-August 2004 , comparable to previous estimates of $30 \pm 5 \mathrm{Tg}$ by Pfister et al. (2005) and $30 \mathrm{Tg}$ by Turquety et al. (2007).

\section{Temporal constraints on biomass burning emissions}

Biomass burning emissions from boreal forest fires show temporal variabilies on different scales. To explore the implications of these variabilities for atmospheric transport of $\mathrm{CO}$ and aerosols, we implemented several additional temporal constraints to the standard monthly GFEDv2 inventory (hereafter monthly GFEDv2).

Forest fires typically last from several days to weeks as seen in MODIS active fires (Giglio et al., 2003). Therefore, we re-sampled the monthly GFEDv2 emissions to an 8-day time step according to MODIS 8-day active fire counts. The resulting 8-day inventory has nearly the same total emissions as the monthly inventory but with a different temporal distribution.

Satellite observations have shown that forest fires exhibit strong diurnal cycles (Giglio, 2007; Prins et al., 1998; Langaas, 1992; Cahoon et al., 1992; Menzel and Prins, 1996; Eva and Lambin, 1998; Pack et al., 2000). Peak burning 


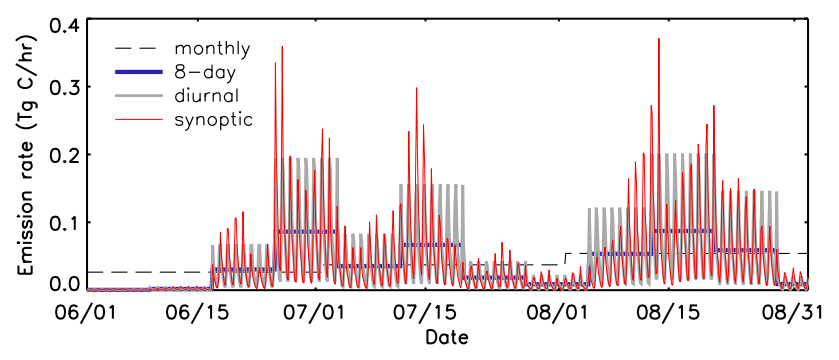

Fig. 1. GFEDv2 time series of total biomass burning emission rates ( Tg C/hr) in North America $\left(180^{\circ}-60^{\circ} \mathrm{W} ; 30^{\circ}-80^{\circ} \mathrm{N}\right)$ for JuneAugust 2004. GFEDv2 inventories with monthly, 8-day, diurnal, and synoptic variations are shown.

typically occurs from 13:00 to 18:30 local time and distinctly earlier in heavily forested regions in the tropics and subtropics (Giglio, 2007). This diurnal cycle, together with the diurnal variability of atmospheric boundary layer, can conceivably influence the transport and deposition of biomass burning emissions. Thus, we were motivated to implement a diurnal cycle to the 8-day GFEDv2 inventory to account for the diurnal variability of forest fires. We used the 8-day GFEDv2 emission inventory as a starting point. We first constructed a mean diurnal cycle with a 3-h time step based on the Automated Biomass Burning Algorithm (ABBA) active fire observations (Prins et al., 1998). The ABBA fire products are available only in the Western Hemisphere from the Geostationary Operational Environmental Satellites (GOES). Specifically, for 5 regions (boreal North America, temperate North America, Central America, northern South America, and southern South America) we constructed mean diurnal cycles of active fires for the four most abundant land cover classes in the MODIS land cover product (MOD12C1v4, UMD cover types). The diurnal cycles from the top four land cover classes were weighted by their relative GFEDv2 emissions to obtain a single mean diurnal cycle for the region.

In the Eastern Hemisphere where there is no GOES coverage, we constructed a mean diurnal cycle using information obtained from the Western Hemisphere. First, we mapped Eastern Hemisphere regions to Western Hemisphere regions based on latitude and land cover. We then used the distribution of MODIS land cover and GFEDv2 emissions in each Eastern Hemisphere region to construct a weighted diurnal cycle from the diurnal cycles for each land cover class in the corresponding Western Hemisphere region. The 3-hourly diurnal coefficients were multiplied by each day's emissions (from 8-day GFEDv2) to derive the diurnal GFEDv2 emission inventory.

It is conceivable that forest fires and the resulting emissions may be influenced by synoptic weather conditions. For example, high wind speed and less precipitation may enhance burning hence emissions while large precipitation may suppress forest fires. It is thus essential to account for this synoptic variability in forest fires. Here we use the Initial Spread Index (ISI, Van Wagner, 1987) for that purpose. ISI indicates the fire favorability of synoptic weather conditions and the expected rate of fire spread. We computed ISI within each GFEDv2 8-day period using GEOS-4 meteorological parameters including temperature, relative humidity, wind speed, and precipitation. These meteorological variables at noon local time were used and re-sampled to $1^{\circ} \times 1^{\circ}$ grids. The exception is precipitation, which was aggregated to $24-\mathrm{h}$ totals. The derived ISI was then used to re-distribute emissions within each 8-day period. This synoptic variability is then superimposed onto the diurnal inventory. This treatment added the day-to-day variation to the diurnal inventory, while keeping the diurnal variation within each day unchanged. The resulting inventory is referred to as synoptic GFEDv2 that combines both diurnal and synoptic variations. We would like to point out that the 8-day GFEDv2 inventory (and the diurnal inventory as a result) likely already includes some synoptic variability. That is because the 8 -day inventory was in part constrained by active fire counts, which are presumably influenced by synoptic weather conditions.

A comparison of the monthly, 8-day, diurnal, and synoptic GFEDv2 inventories is shown in Fig. 1 for North America $\left(180^{\circ}-60^{\circ} \mathrm{W} ; 30^{\circ}-80^{\circ} \mathrm{N}\right)$ during the summer 2004 fire season. Emissions increased from June to August in the monthly inventory. The higher-temporal resolution inventories, especially the diurnal and synoptic inventories indicate that large emissions were concentrated in short periods. Major fires and associated emissions occur in late June through early July, in mid-July, and throughout much of August. Significant diurnal variations are seen in the diurnal and synoptic inventories. The synoptic inventory shows large day-to-day variability. The general features of day-to-day variation in our synoptic inventory are very similar to that in the fire emission inventories derived by Pfister et al. (2005) and Turquety et al. (2007). However, in comparison to these two inventories, our synoptic inventory has lower emission rate during late July and higher emission rate during mid-August.

\section{Injection heights of biomass burning emissions}

There is ample evidence that biomass burning smoke plumes can be injected well above the PBL (Kahn et al., 2008; Fromm et al., 2005). Recent modeling studies also show that some smoke plumes have to be injected into the free troposphere for improved model comparison with observations (Turquety et al., 2007; Leung et al., 2007). This rising of smoke plumes is thought to be related to the dynamical heat flux from fires, convolved with the atmospheric stability structure (Kahn et al., 2007), and the associated moist convective processes (Fromm et al., 2005). These mechanisms have been implemented and examined in several highresolution modeling studies (e.g. Luderer et al., 2006; Trentmann et al., 2002, 2006), which showed strong sensitivity of 
the pyro-convection to background meteorology. We examine here the effects of different plume injection height parameterizations on the model simulation of biomass burning long-range transport.

It is conceivable that the pyro-convection at the fire sources shows distinct characteristics compared with the passive convection driven by the meteorology. Fire-produced buoyancy is naturally associated with abundant pollutants such as $\mathrm{CO}, \mathrm{NO}_{\mathrm{x}}$, and smoke, therefore the potential for significant atmospheric impact is much greater than for thermal convection unrelated to fire (Fromm et al., 2005). However, many previous modeling studies release biomass burning emissions exclusively within the PBL, which does not explicitly treat the fire-induced convection. To represent pyroconvection processes in model simulations, biomass burning emissions can be injected to different vertical layers, emulating the effect of fast vertical mixing in the source regions. Recently, some efforts have been made to derive this injection height from the energy of fires and the stability of local atmosphere through empirically- (Lavoué et al., 2000) or physically-based (Freitas et al., 2006, 2007) parameterizations. However, the empirical parameterizations were usually derived from limited observations and may not apply to other smoke plumes. The physically-based methods require accurate measurements of fire energy and local meteorology, which are often not available. Direct observations of forest fire injection height to validate these injection models are still sparse. Space-based remote sensing instruments are beginning to provide measurements of injection heights in fire source regions using stereo imaging (e.g. Kahn et al., 2007; Val Martin et al., 2009), and smoke plume heights downwind from active sensors such as the CALIPSO Lidar (Labonne et al., 2007).

A new stereoscopy-based technique has been recently developed to determine smoke plume injection height from satellite observations (Kahn et al., 2007, 2008; Nelson et al., 2008; Moroney et al., 2002). In this method, smoke plumes were identified using the MODIS thermal anomaly and the multi-angular images from the Multi-angle Imaging SpectroRadiometer (MISR). The wind-corrected height for each smoke pixel was derived using a high-resolution stereomatching technique, with an uncertainty of about $\pm 500 \mathrm{~m}$ (Naud et al., 2005). This new approach represents a refinement of that developed for the MISR Standard Stereo Height product (Moroney et al., 2002). Detailed validation of the MISR-derived plume height is still challenging due to limited coverage of MISR measurements and the lack of coincident in situ observations. For some smoke, the fires occur outside the MISR field-of-view, and sometimes for other reasons, it can be difficult to determine the evolution of plume height. In these cases, it is uncertain whether the smoke was injected or advected by regional meteorology to the observed heights. We called such events smoke clouds, and assume the derived heights represent the actual injection heights. Based on this method, plume heights for more than 600 smoke plumes and

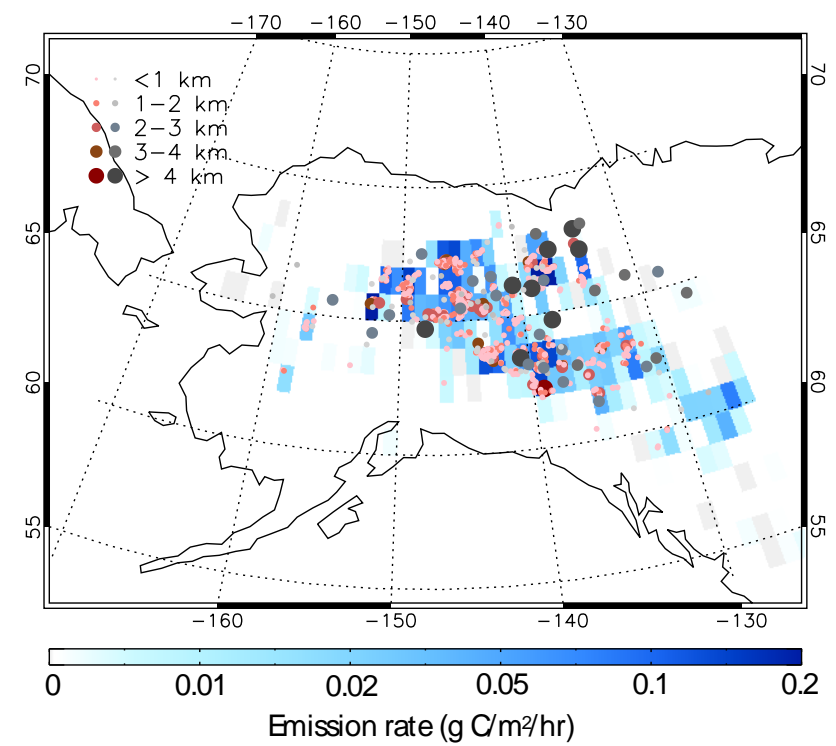

Fig. 2. Spatial distribution of GFEDv2 emissions $\left(\mathrm{g} \mathrm{C}^{2} \mathrm{~m}^{2} / \mathrm{hr}\right)$ in Alaska and western Canada during June-August 2004 (blue). Also shown are MISR-derived heights of smoke plumes (brown circles) and smoke clouds (grey circles). Data are from Nelson et al. (2008).

smoke clouds over Alaska and the Yukon Territory during the summer of 2004 have been derived (Fig. 2). The average, maximum, and minimum plume heights observed during this period were $0.97 \mathrm{~km}, 4.5 \mathrm{~km}$, and $0.18 \mathrm{~km}$, respectively. We found between $10 \%$ and $30 \%$ of smoke plumes reached the free troposphere, even considering the uncertainties in smoke plume height retrieval and PBL height (Kahn et al., 2008).

To investigate the impact of plume injection height, we conducted GEOS-Chem simulations with four different treatments of biomass burning emissions, with or without vertical injection above the PBL. In the base simulation, emissions are evenly distributed throughout the PBL (hereafter referred to as $A l l P B L)$. Obviously this approach underestimates emissions injected into the free troposphere. In the second simulation, we distribute emissions vertically based upon statistical distributions of observed plume heights. Specifically, we derived a probability distribution function (PDF) of the MISR plume heights mentioned above. Biomass burning emissions in each model grid box are then distributed vertically according to this PDF (hereafter referred to as MIS$R p d f$ ). This approach is not realistic in that not all plumes rise above the boundary layer in the real atmosphere. On the other hand, one might expect a correlation between high emissions and high plume heights. By assuming all individual smoke plumes follow a single PDF, this method may underestimate the fire emissions injected at the highest altitudes. Plumes injected at high altitudes generally result from intense burning over a large area and are often associated with large emissions (see Fig. 2). In the third simulation, we treat these high rising smoke plumes and smoke clouds 


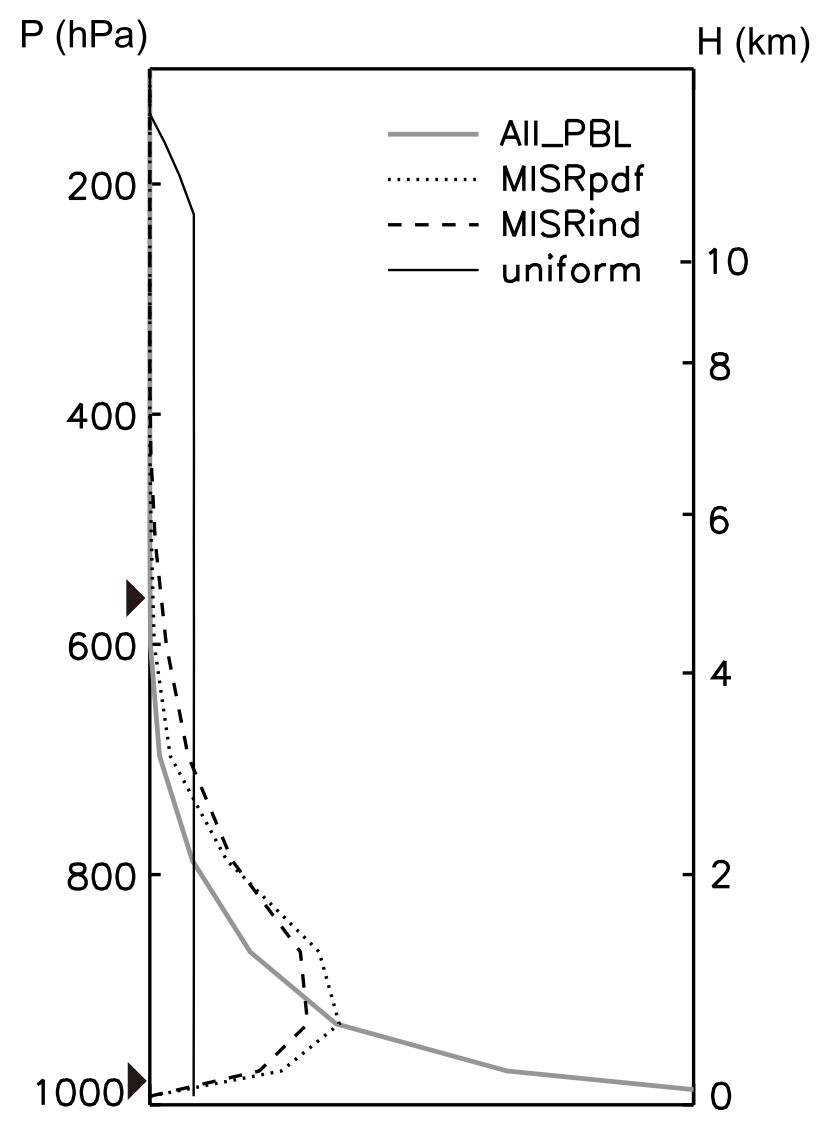

\section{Normalized emission rate}

Fig. 3. Vertical profiles for releasing biomass burning emissions in Alaska and western Canada during summer 2004, calculated using All_PBL, MISRpdf, MISRind, and uniform injection height distributions as described in Table 1 . The two triangles represent the altitudes of maximum and minimum injection heights as observed by MISR in Alaska and western Canada during summer 2004.

individually (hereafter referred to as MISRind). In this approach, when the height of a smoke plume or cloud is more than $2 \mathrm{~km}$ above terrain, as observed by MISR, emissions in the model grid box containing the plume are released to the model layer corresponding to the MISR-derived plume height. Since fires usually last for several days, we assume that this high-altitude injection lasts through the 8-day period. A single PDF profile derived from the rest plumes is used to distribute other fire emissions into model vertical layers. On average, about $10 \%$ of the emissions are from those plumes individually treated in the simulation. This approach is based upon the hypothesis that the most intense fires (area and biomass burned, energy release, emissions, etc.) followed by injection to high altitudes contribute the most to the long-range transport of biomass burning emissions. Since the MISR smoke plume height product we used only includes Alaska and western Canada, we applied the MISR derived profiles (MISRpdf and MISRind) to these regions only. In other regions, including central Canada where considerable fires were present during the summer 2004, we still use the $A L L \_P B L$ distribution. Lastly, we conducted a simulation in which biomass burning emissions were uniformly (in mass mixing ratio) distributed through the tropospheric column up to $200 \mathrm{hPa}$ (hereafter referred to as uniform). This approach is similar to that used in several previous studies (Leung et al., 2007; Turquety et al., 2007; Hyer et al., 2007) although we choose a simpler average configuration. It clearly represents an extreme scenario in which certain percentages of emissions from each boreal forest fire were injected to the middle and upper troposphere. The four vertical profiles for plume injection, All_PBL, MISRpdf, MISRind, and uniform are shown in Fig. 3.

\section{Model simulations and observations}

To examine the effects of the temporal and vertical constraints on biomass burning emissions, we conducted GEOSChem simulations of $\mathrm{CO}$ and aerosols in which the GFEDv2 biomass burning emissions inventories described in the previous sections were used. In the $\mathrm{CO}$ simulation, we track $\mathrm{CO}$ emitted from different source types and regions. This enables the separation of North American forest fire emissions of CO from other sources and/or regions. The simulations were conducted for January-August 2004 with the first five months as initialization. Our analysis focuses on the last three months, June-August. We archived model output of 3$h$ average concentrations of tagged $\mathrm{CO}$ tracers and aerosols.

In the first four GEOS-Chem simulations, GFEDv2 emissions were uniformly distributed within the boundary layer but with monthly, 8-day, diurnal, and synoptic temporal variations, respectively. We conducted three additional simulations where the MISRpdf, MISRind, and uniform biomass burning injection height profiles were applied to the synoptic GFEDv2 inventory. To isolate the effects of North American boreal forest fires (mostly in Alaska and western Canada) from other sources, we also conducted a simulation in which North American biomass burning emissions were shut off (hereafter referred to as nobbNA). Additionally, we conducted simulations with moist convection turned off to assess the importance of this factor relative to the various temporal and vertical constraints on the export of boreal forest fire smoke subsequent to emissions. Specifically, we conducted three sensitivity tagged $\mathrm{CO}$ simulations in which moist convection is turned off while biomass burning emissions were prescribed using the synoptic GFEDv2 with allin-PBL injection, synoptic GFEDv2 plus MISRind injection, and synoptic GFEDv2 plus uniform injection (referred to as synoptic-noconv, MISRind-noconv, and uniform-noconv, respectively). A summary of the different GEOS-Chem simulations is presented in Table 1. 
Table 1. GEOS-Chem simulations with different GFEDv2 biomass burning emission inventories (different temporal distributions and plume injection heights) and with or without convection.

\begin{tabular}{|c|c|c|c|c|c|c|c|c|c|c|}
\hline \multirow[t]{2}{*}{ Name } & \multicolumn{4}{|c|}{ Temporal distribution } & \multicolumn{4}{|c|}{ Plume injection height } & \multirow{2}{*}{$\begin{array}{c}\text { North } \\
\text { America } \\
\text { biomass } \\
\text { burning }\end{array}$} & \multirow[t]{2}{*}{ Convection } \\
\hline & $\begin{array}{l}\text { monthly } \\
\text { resolved }\end{array}$ & $\begin{array}{l}\text { 8-day } \\
\text { resolved }\end{array}$ & $\begin{array}{l}\text { diurnal } \\
\text { cycle }\end{array}$ & $\begin{array}{l}\text { synoptic } \\
\text { variation }\end{array}$ & all_PBL $^{1}$ & MISRpdf $^{2}$ & MISRind $^{3}$ & uniform ${ }^{4}$ & & \\
\hline monthly & $\mathrm{x}$ & & & & $\mathrm{x}$ & & & & $\mathrm{x}$ & $\mathrm{x}$ \\
\hline 8-day & & $\mathrm{x}$ & & & $\mathrm{x}$ & & & & $\mathrm{x}$ & $\mathrm{x}$ \\
\hline diurnal & & $\mathrm{x}$ & $\mathrm{x}$ & & $\mathrm{x}$ & & & & $\mathrm{x}$ & $\mathrm{x}$ \\
\hline synoptic & & $\mathrm{x}$ & $\mathrm{x}$ & $\mathrm{x}$ & $\mathrm{x}$ & & & & $\mathrm{x}$ & $\mathrm{x}$ \\
\hline MISRpdf & & $\mathrm{x}$ & $\mathrm{x}$ & $\mathrm{x}$ & & $\mathrm{x}$ & & & $\mathrm{x}$ & $\mathrm{x}$ \\
\hline MISRind & & $\mathrm{x}$ & $\mathrm{x}$ & $\mathrm{x}$ & & & & & $\mathrm{x}$ & $\mathrm{x}$ \\
\hline uniform & & $\mathrm{x}$ & $\mathrm{x}$ & $\mathrm{x}$ & & & & $\mathrm{x}$ & $\mathrm{x}$ & $\mathrm{x}$ \\
\hline nobbNA & & $\mathrm{x}$ & $\mathrm{x}$ & $\mathrm{x}$ & $\mathrm{x}$ & & & & & $\mathrm{x}$ \\
\hline synoptic-noconv & & $\mathrm{x}$ & $\mathrm{x}$ & $\mathrm{x}$ & $\mathrm{x}$ & & & & $\mathrm{x}$ & \\
\hline MISRind-noconv & & $\mathrm{x}$ & $\mathrm{x}$ & $\mathrm{x}$ & & & $\mathrm{x}$ & & $\mathrm{x}$ & \\
\hline uniform-noconv & & $\mathrm{x}$ & $\mathrm{x}$ & $\mathrm{x}$ & & & & $\mathrm{x}$ & $\mathrm{x}$ & \\
\hline
\end{tabular}

1 all_PBL: uniformly released throughout the PBL.

${ }^{2}$ MISRpdf: vertically dirstributed according to a probability distribution function (PDF) of MISR-derived plume heights.

${ }^{3}$ MISRind: similar to MISRpdf, but with high smoke plumes treated indivicually.

${ }^{4}$ uniform: uniformly released throughout the tropospheric column up to $200 \mathrm{hPA}$.

To evaluate the model performance, we compared model results with aircraft, satellite, and ground-based observations of $\mathrm{CO}$ and aerosols. The INtercontinental chemical Transport EXperiment - North America (INTEX-NA) (Singh et al., 2006) was conducted over the continental United States and western North Atlantic during the summer of 2004. A focus of this experiment was to quantify and characterize the inflow and outflow of aerosols and trace gases over North America. We used the 5-min aggregated CO mixing ratio and aerosol absorption data from INTEX-NA, for which the NASA DC-8 was the principle platform. The measured $530 \mathrm{~nm}$ absorption coefficient $\left(b_{\mathrm{abs}}, \mathrm{m}^{-1}\right)$ from Particle Soot Absorption Photometers was used to derive the BC mass concentration $\left(M, \mathrm{~g} / \mathrm{m}^{3}\right)$ as follows: $M=\frac{b_{\mathrm{abs}}}{E_{\mathrm{abs}}}$, where $E_{\text {abs }}=10 \mathrm{~m}^{2} \mathrm{~g}^{-1}$ is the assumed BC mass absorption efficiency (Horvath, 1993; Andreae and Gelencsér, 2006). Vertical profiles of $\mathrm{CO}$ mixing ratio and $\mathrm{BC}$ mass concentration were derived from the DC-8 measurements and compared with GEOS-Chem results.

The Measurement of Pollution in the Troposphere (MOPITT) instrument aboard the Earth Observing System (EOS) Terra satellite measures upwelling infrared radiation and has been retrieving $\mathrm{CO}$ mixing ratios and total column amounts since 2000 (Drummond et al., 1996; Deeter et al., 2003). $\mathrm{CO}$ mixing ratios are reported for six pressure levels: 850 , $700,500,350,250,150 \mathrm{hPa}$, and at the surface, for global clear-sky measurements. The retrieved CO profile is a linear combination of the true profile and a fixed a priori profile.
MOPITT also retrieves CO column, which is the integral of the $\mathrm{CO}$ mixing ratio at each level, using an averaging kernel that is most sensitive to the middle troposphere (Deeter et al., 2003). MOPITT views the Earth with a $22 \mathrm{~km} \times 22 \mathrm{~km}$ spatial resolution and covers the entire globe every 3 days. In this study, we compare spatial distribution and time series of CO column over North America from the model simulations with the MOPITT V3 Level 3 (MOP03, gridded daily averages) $\mathrm{CO}$ retrievals. Only the daytime (10:45 local time) MOPITT CO columns were used in our comparison because the nighttime measurements have not been validated (Heald et al., 2004).

Two surface observation networks provide aerosol measurements that can be used for comparison with our model results. The EPA Interagency Monitoring of PROtected Visual Experiments (IMPROVE) program (Chow and Watson, 2002) has been measuring air quality parameters in United States since 1985 (http://vista.cira.colostate.edu/improve/). The IMPROVE network monitored surface level aerosols and optical properties at 175 sites in the summer of 2004. 24$\mathrm{h}$ average samples were collected every 3 days. The IMPROVE aerosol samplers contained four modules with different filters to collect and analyze aerosol concentration and composition. In this study, we used surface BC concentrations analyzed from the quartz filters for comparison with GEOS-Chem results. Only data with quality control flag "NM (normal)" or "CG (cogged filter with the final flow rate greater than one-half of the initial flow rate)" were used in this analysis. 
NASA's AErosol RObotic NETwork (AERONET, Holben et al., 1998) provides globally distributed near real time observations of aerosol spectral optical depths at wavelengths of $340,380,440,500,670,870,940$ and $1020 \mathrm{~nm}$ (Holben et al., 1998). During the summer of 2004, there were more than 80 automatic Sun-sky spectral radiometer sites operating. In this study we compared model simulated aerosol results against AERONET Level 2.0 cloud-screened, qualityassured $500 \mathrm{~nm}$ AOD data (Smirnov et al., 2000).

We used CO from MOPITT and aircraft measurements to compare with our simulation because these measurements provided $\mathrm{CO}$ information in the middle and upper troposphere, where the long-range transport has largest effect. Measurements of surface $\mathrm{CO}$ are also available, but the variability of surface $\mathrm{CO}$ is often dominated by other factors such as fossil fuel emissions. Therefore it is difficult to use these measurements to assess the importance of temporal variability and injection height of biomass burning. In addition to aerosol measurements from IMPROVE and AERONET, we also compared model results with AOD products from satellite remote sensing instruments (e.g. MODIS and MISR). Initial results showed that the differences between different model simulations are much smaller than the modelobservation difference and MODIS-MISR difference. Thus we will not present these comparisons in this study.

\section{Results}

\subsection{Simulated $\mathrm{CO}$ and $\mathrm{BC}$ in response to biomass burning emission temporal and vertical distribution}

The primary goal of this study is to assess the impact of various temporal and vertical emission distributions on the transport and mixing of North American biomass burning $\mathrm{CO}$ and aerosols. In this section, we compare the $\mathrm{CO}$ and $\mathrm{BC}$ results from different GEOS-Chem simulations as summarized in Table 1. The differences among the model simulations can then be attributed to different temporal and/or vertical distributions of biomass burning emissions. We present the comparisons of $\mathrm{CO}$ mixing ratios in different model layers in 6.1.1. In 6.1.2, we show how the temporal distributions and injection heights of biomass burning emissions affect $\mathrm{CO}$ and $\mathrm{BC}$ total column burdens in North America.

\subsection{CO mixing ratios}

Modeled CO mixing ratios at five pressure levels (surface, $850 \mathrm{hPa}, 700 \mathrm{hPa}, 500 \mathrm{hPa}, 300 \mathrm{hPa}$ ) over North America and adjacent oceans from the monthly simulation are shown in the left column of Fig. 4. The values are averages for JuneAugust 2004. In addition to the anthropogenic emissions over the Midwest and East Coast, emissions from boreal forest fires in Alaska and western Canada and their subsequent long-range transport lead to widespread enhancement in $\mathrm{CO}$ throughout the lower to middle troposphere.

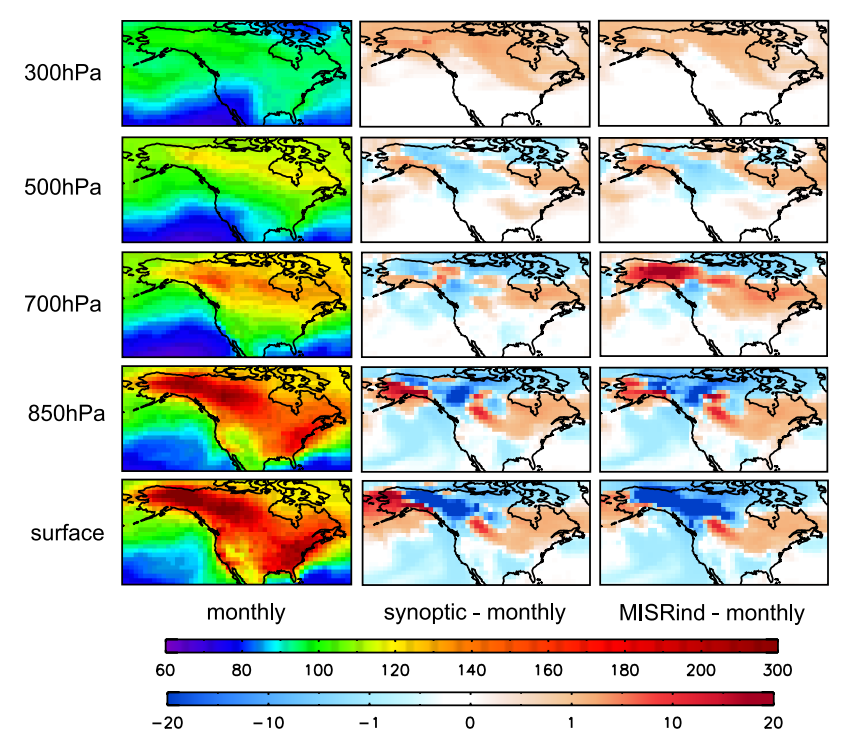

Fig. 4. Model simulated 3-month (June-August 2004) average $\mathrm{CO}$ mixing ratios (ppbv) at five pressure layers (surface, $850 \mathrm{hPa}$, $700 \mathrm{hPa}, 500 \mathrm{hPa}, 300 \mathrm{hPa}$ ) from the monthly simulation, and the differences due to the adding of temporal constraints (synoptic monthly), and due to the adding of both temporal constraints and MISRind injection height of biomass burning emissions (MISRind - monthly).

In comparison with the monthly simulation, effects of additional temporal and vertical constraints are clearly seen in the middle (synoptic - monthly) and right (MISRind monthly) columns of Fig. 4. The difference between the synoptic and monthly simulations (middle column, Fig. 4) represents the cumulative effect of all three temporal constraints, i.e. the 8-day redistribution, the diurnal cycle, and the synoptic day-to-day variation. Relative to the monthly simulation, the synoptic simulation decreases $\mathrm{CO}$ levels throughout the tropospheric column over the biomass burning source regions, and increases CO levels downwind of the source regions. The largest increase occurs at $300 \mathrm{hPa}$ over much of North America.

These differences obviously result from the combined effects of both the temporal distributions of biomass burning emissions and meteorological conditions. To illustrate this point, we calculated the mean values of horizontal wind speeds and deep convective mass fluxes from the GEOS4 meteorological fields over Alaska and western Canada, weighted by biomass burning emissions from GFEDv2. The results are summarized in Table 2. Averaged over JuneAugust 2004, the emission-weighted convective mass fluxes from the synoptic simulation are higher than those from the monthly simulation at all pressure levels. This suggests that with emissions distributed over 8-day or shorter time intervals, roughly the durations of major fire events, more $\mathrm{CO}$ is transported out of the boundary layer into the free troposphere. Additionally, the emission-weighted mean horizontal 
Table 2. Biomass burning emission-weighted mean meridional (V) winds (m/s), zonal (U) winds (m/s), and deep convective mass fluxes $\left(10^{-2} \mathrm{~Pa} / \mathrm{s}\right)$ over Alaska and western Canada during summer 2004. Positive values indicate eastward, northward and upward winds and fluxes.

\begin{tabular}{l|ccc|cccc|ccc}
\hline & \multicolumn{3}{|c}{ Meridional Wind (V) } & \multicolumn{3}{c}{ Zonal Wind (U) } & \multicolumn{3}{c}{ Deep Convective Mass Flux } \\
& monthly & 8-day & synoptic & monthly & 8-day & synoptic & monthly & 8-day & synoptic \\
\hline Surface & -3.15 & -4.44 & -3.24 & 5.09 & 4.30 & 4.02 & 2.77 & 2.46 & 2.91 \\
$850 \mathrm{hPa}$ & -6.64 & -9.34 & -7.81 & 11.68 & 11.08 & 11.70 & 1.94 & 1.76 & 2.16 \\
$700 \mathrm{hPa}$ & -11.46 & -16.56 & -14.27 & 18.78 & 19.13 & 21.28 & 1.49 & 1.70 & 2.24 \\
$500 \mathrm{hPa}$ & -17.17 & -25.79 & -22.10 & 26.78 & 28.07 & 31.86 & 0.75 & 1.09 & 1.61 \\
$300 \mathrm{hPa}$ & -23.73 & -36.97 & -33.20 & 38.51 & 40.49 & 47.15 & 0.02 & 0.03 & 0.04 \\
\hline
\end{tabular}

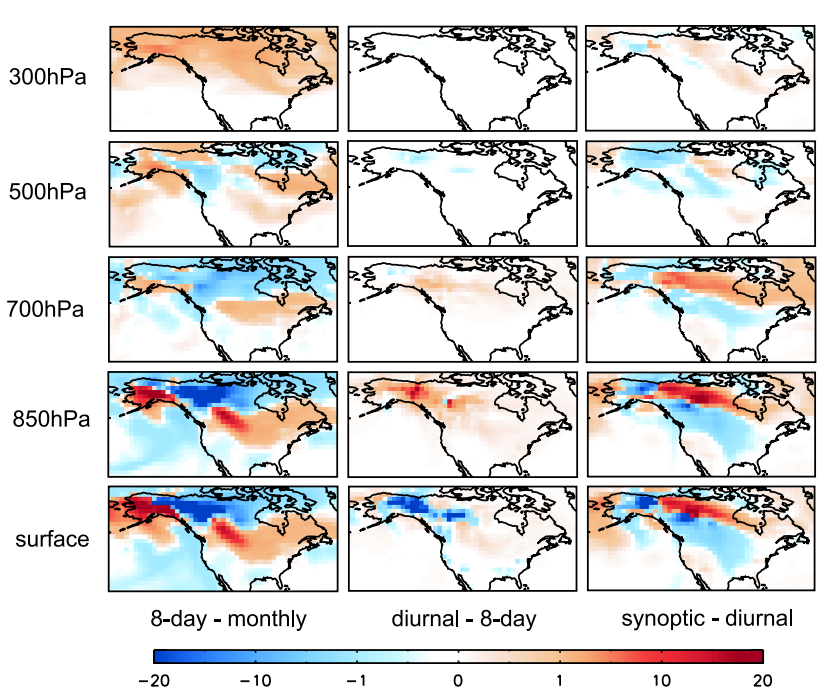

Fig. 5. Differences of model simulated 3-month (JuneAugust 2004) average $\mathrm{CO}$ mixing ratios (ppbv) at five pressure layers (surface, $850 \mathrm{hPa}, 700 \mathrm{hPa}, 500 \mathrm{hPa}, 300 \mathrm{hPa}$ ) due to the adding of each temporal constraint on biomass burning emissions.

wind speeds are also higher in the synoptic simulation (see Table 2), indicating stronger horizontal advection of CO.

Going from monthly to synoptic GFEDv2 not only enhances transport, but also changes the transport direction. For example, negative values over the sub-Arctic regions in Fig. 4 indicate that the northward transport is decreased in the synoptic simulation. On the other hand, increased influence of biomass burning $\mathrm{CO}$ is seen at mid-latitude North America in the synoptic simulation. This is consistent with the much stronger, southward (negative values), emissionweighted meridional winds in the synoptic simulation at all pressure levels (Table 2).

Also shown in Fig. 4 (right column) are the changes in $\mathrm{CO}$ mixing ratios relative to the monthly simulation when both the temporal constraints and MISR-derived injection heights were used (MISRind - monthly). The spatial patterns outside of fire source regions are similar to those of synoptic - monthly (Fig. 4, middle column), indicating that the overall effect of plume vertical injection as implemented in MISRind is smaller than that of the temporal distributions. However, in the source regions, the use of MISRind vertical distribution significantly increases the $\mathrm{CO}$ mixing ratios at $700 \mathrm{hPa}$ while decreases $\mathrm{CO}$ at the surface. The enhancement of $\mathrm{CO}$ at $700 \mathrm{hPa}$ over eastern North America is also stronger than that of synoptic - monthly.

Figure 5 shows the relative importance of each temporal constraint. A mean diurnal cycle as implemented in the model has a relatively minor effect on the export and longrange transport of biomass burning $\mathrm{CO}$. It somewhat decreases the surface $\mathrm{CO}$ level while increasing $\mathrm{CO}$ mixing ratios at high altitudes (Fig. 5, middle column). Matichuk et al. (2007) studied the effect of a diurnal cycle on biomass burning aerosols in southern Africa and reached similar conclusions.

Relative to the inclusion of a diurnal cycle, going from monthly to 8-day GFEDv2 inventory (Fig. 5, left column) and the inclusion of a synoptic constraint (Fig. 5, right column) lead to larger changes in simulated CO distribution. Compared to the monthly simulation, the use of the 8-day GFEDv2 enhances the southward transport and therefore increases the $\mathrm{CO}$ mixing ratios in southern Canada and northern US. This change can also be linked to the increased coincidence of fire emissions and southward winds (see Table 2). With the use of the synoptic constraint, the enhancement of southward transport is decreased. More transport is toward the high latitudes over northeastern Canada.

Changes of CO spatial pattern due to different treatments of biomass burning emission injection heights are shown in Fig. 6. We present results from three injection height distributions: MISRpdf, MISRind, and uniform. Relative to a synoptic simulation in which all biomass burning emissions are distributed within the PBL, the two MISR-based injection height profiles, MISRpdf and MISRind, produce higher CO mixing ratios in the middle troposphere and lower $\mathrm{CO}$ at surface. Among the five levels, the largest increase in $\mathrm{CO}$ from the MISRpdf simulation occurs at $850 \mathrm{hPa}$, which is compatible with the largest difference of biomass emissions between 


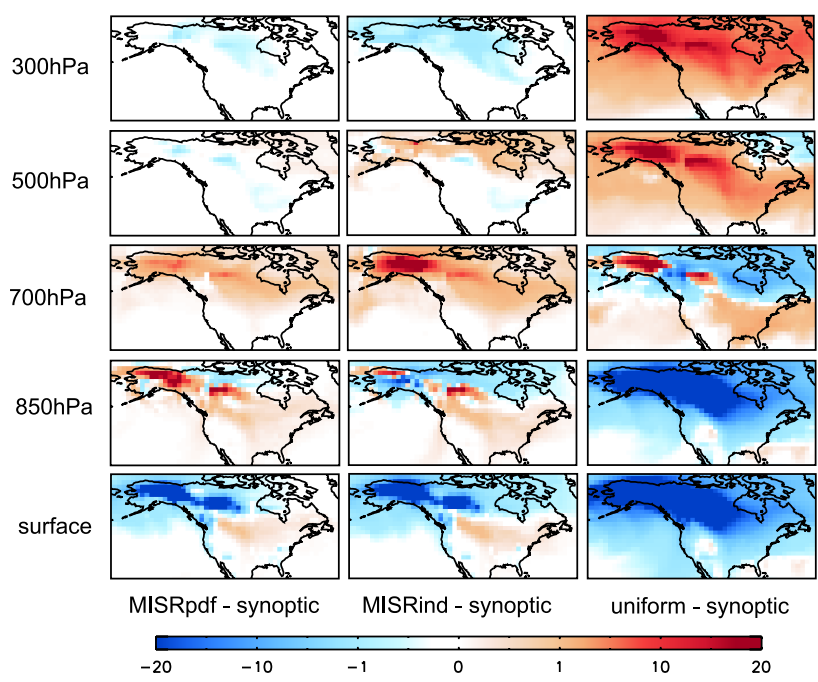

Fig. 6. Differences of model simulated 3-month (JuneAugust 2004) average CO mixing ratios (ppbv) at five pressure layers (surface, $850 \mathrm{hPa}, 700 \mathrm{hPa}, 500 \mathrm{hPa}, 300 \mathrm{hPa}$ ) due to the use of each injection height distribution of biomass burning emissions.

the MISRpdf and All PBL distributions (Fig. 3). Since most high smoke plumes individually treated in the MISRind distribution reside between $600 \mathrm{hPa}$ and $800 \mathrm{hPa}$, the MISRind simulation also shows large increase of $\mathrm{CO}$ at $700 \mathrm{hPa}$. The increase of $\mathrm{CO}$ is also seen up to the $500 \mathrm{hPa}$ level over high latitudes. By injecting much more emissions into higher altitudes (Fig. 3), the uniform distribution significantly decreases the $\mathrm{CO}$ mixing ratios in the lower troposphere and increases $\mathrm{CO}$ in the upper troposphere. The affected region covers a much larger area than that from the MISRpdf or MISRind simulations.

We also calculated the $\mathrm{BC}$ concentration changes due to the use of different biomass burning emission temporal distributions and injection height distributions (not shown here). Overall the effects are similar to that for $\mathrm{CO}$ mixing ratios shown in Figs. 4-6. A noticeable difference is that the effects on $\mathrm{BC}$ at high altitudes are much smaller than for $\mathrm{CO}$. In addition, the domain in which injection height reduces the surface BC concentration is smaller than that for CO.

\subsection{Column burdens}

In this section, we investigate the sensitivity of $\mathrm{CO}$ and $\mathrm{BC}$ column burdens to different biomass burning emission temporal distributions and injection height profiles. Figure 7 shows the changes of 3-month (June-August 2004) average $\mathrm{CO}$ and $\mathrm{BC}$ column burdens after using the temporal constraints, the MISR-derived injection height distributions, and both. Since the relative differences of $\mathrm{CO}$ and $\mathrm{BC}$ column burdens between the MISRpdf and MISRind simulations are small, hereafter we only concentrate on the MISRind simulation.

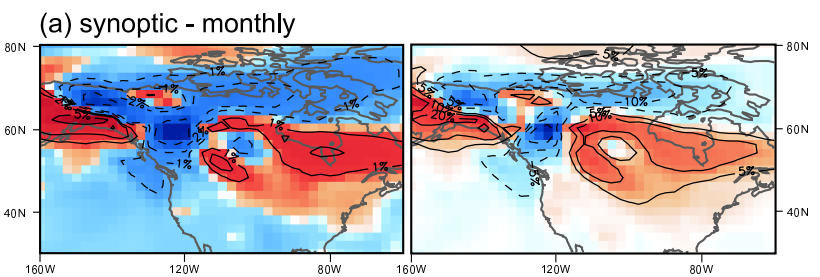

(b) MISRind - synoptic

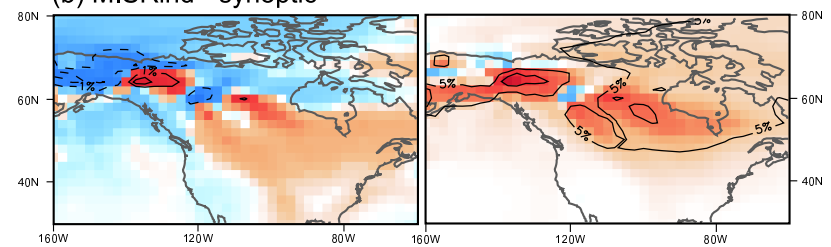

(c) MISRind - monthly

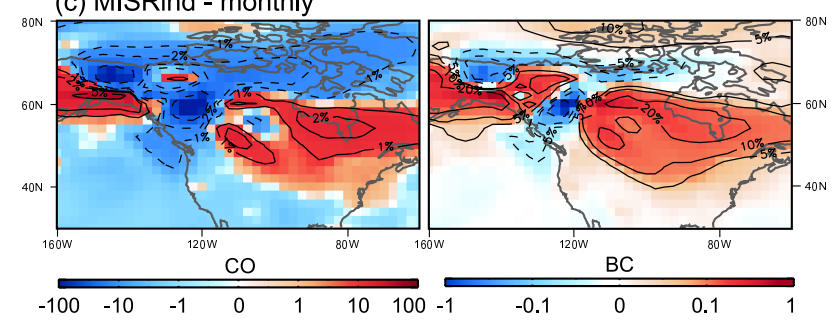

Fig. 7. Impacts of biomass burning emission temporal and injection height distribution on simulated 3-month (June-August 2004) average $\mathrm{CO}$ (left columns) and BC (right columns) column burdens in North America. The absolute differences $\left(\mathrm{kg} / \mathrm{km}^{2}\right)$ are shown in red and blue grid cells. The relative changes (in percentage) are shown in line contours.

With biomass burning emission temporal constraints added, more emissions are distributed during shorter intervals. Previous discussions on Fig. 4 and Table 2 show that emissions during these shorter intervals are subject to stronger convection and southward transport. Therefore, the $\mathrm{CO}$ and $\mathrm{BC}$ column burdens are reduced in the source regions and increased in the downwind regions, particularly south of $60^{\circ} \mathrm{N}$, as evident in the difference between the synoptic and monthly simulations (Fig. 7a). The MISRind simulation includes all the temporal constraints (8-day, diurnal, and synoptic) therefore the difference between the MISRind and synoptic simulations is attributed to the effect of plume injection (see Sect. 4). Lifetimes of pollutants including $\mathrm{CO}$ and $\mathrm{BC}$ are typically longer in the free troposphere. Thus the overall effect of applying the MISRind vertical distribution is decreasing the $\mathrm{CO}$ and $\mathrm{BC}$ burdens in the biomass burning source regions and increasing them downwind, as shown in the difference between the MISRind and synoptic simulations (Fig. 7b). The combined effect of including both the temporal constraints and MISR-derived emissions injection height distributions, as the difference between the MISRind and monthly simulations shows, is mainly determined by the temporal constraints (Fig. 7c).

The changes of $\mathrm{CO}$ and $\mathrm{BC}$ column burdens when applying the temporal and/or vertical injection constraints are 

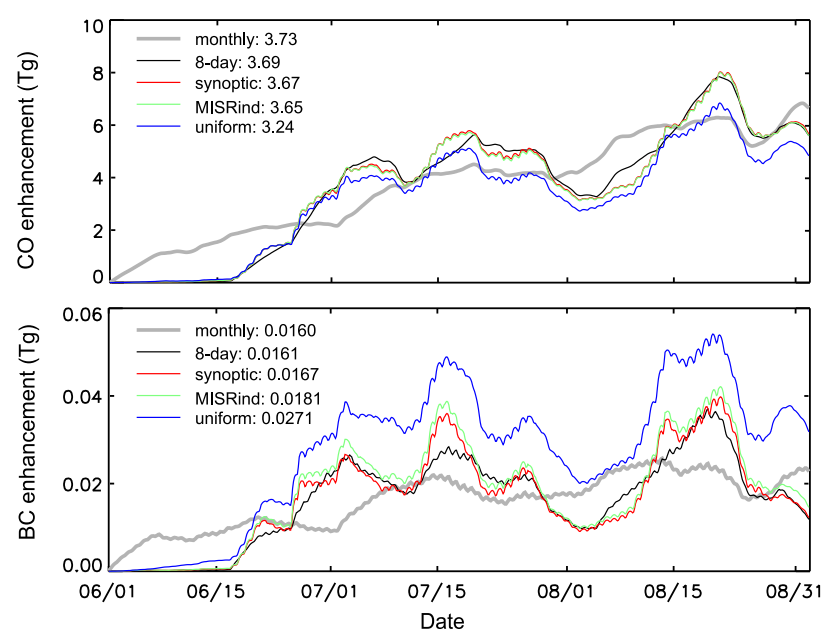

Fig. 8. Time series of enhanced total $\mathrm{CO}$ and $\mathrm{BC}$ burdens $(\mathrm{Tg})$ in North America (180 W-60 W, 30 N-80 N) for June-August 2004. The enhancement is the difference between simulated CO/BC burden and that from the nobbNA simulation. The 3-month mean values for the enhancement from each simulation are shown in the legend.

considerably different. Relative to $\mathrm{CO}, \mathrm{BC}$ burden decreases in a smaller region near the biomass burning sources, as expected, considering the shorter lifetime of BC. Over eastern North America, the use of temporal constraints and MISRind injection height increases BC burden as much as $20 \%$, whereas the largest change in $\mathrm{CO}$ burden is only about $2 \%$ (Fig. 7c).

Figure 8 shows GEOS-Chem simulated time series of $\mathrm{CO}$ and $\mathrm{BC}$ burden enhancements within the North American domain, defined as $180^{\circ}-60^{\circ} \mathrm{W}, 30^{\circ}-80^{\circ} \mathrm{N}$, during JuneAugust 2004. The enhancements were calculated as the difference between the nobbNA simulation in which North American biomass burning (mostly in Alaska and western Canada) were turned off, and other simulations (see Table 1). The larger slopes in Fig. 8 correspond to intensive emissions shown in Fig. 1. Overall, the use of emissions with higher temporal resolutions shows more temporal variability, and generally increases the enhancements during periods of extensive fire occurrences such as later June, mid-July, and mid-August. However, there is no significant change in the three-month mean values (shown in the legend of Fig. 8) of enhancements for $\mathrm{CO}$ and $\mathrm{BC}$ from simulations with different temporal distributions of emissions. We also notice that in the monthly and 8-day simulations in which the diurnal variability of biomass emissions is not represented, a diurnal cycle of total burden is clearly seen for BC, but not for $\mathrm{CO}$. This diurnal signal of the $\mathrm{BC}$ burden, not to be confused with that from diurnal cycle of fires, may originate from the diurnal patterns of aerosol removal processes (Nicholson, 1988).

Figure 8 also demonstrates the difference between the injection height effects on $\mathrm{BC}$ and $\mathrm{CO}$. The MISRind and uniform simulations, especially the latter, show large increases of total $\mathrm{BC}$ burdens due to longer lifetimes of $\mathrm{BC}$ once injected into the free troposphere. Therefore, the total BC enhancement is larger when some fire emissions are above the PBL (MISRind and uniform). The consequence for the $\mathrm{CO}$ burden, however, is the opposite. The amount of increased CO transported out of the North American domain is so large that increased transport removal outweighs the increase of $\mathrm{CO}$ burden within the domain due to the longer lifetime.

\subsection{Comparison of modeled $\mathrm{CO}$ and $\mathrm{BC}$ vertical profiles with INTEX-NA observations}

The role of biomass burning injection height distribution in affecting the simulated vertical profiles of trace gases and aerosols is discussed in this section. We compared our model results with DC-8 aircraft measurements during the INTEXNA experiment over eastern North America (Fig. 9). We compared $\mathrm{CO}$ and $\mathrm{BC}$ vertical profiles averaged for the entire INTEX-NA period and from specific flights. In the latter case, the selected flights correspond to days with apparent influence of forest fires in Alaska and western Canada. GEOS-Chem results are sampled along the flight tracks at the time of measurements (see http://www.espo.nasa.gov/ intex-na/flight_reps.html).

Overall, GEOS-Chem captures the main features of the mean and individual $\mathrm{CO}$ profiles (Fig. 9a, b), even with biomass burning emissions distributed within the PBL only (in the synoptic simulation). The largest bias occurs in the low troposphere, where the model overestimates the $\mathrm{CO}$ mixing ratios. This may be due to several factors including emission estimates that are too high, or by model biases such as $\mathrm{OH}$ levels that are too low, or convection that is too weak. Detailed exploration of this discrepancy is beyond the scope of this paper. Due to the different temporal and spatial scales between model results and the INTEX-NA measurements, GEOS-Chem is not expected to capture some extreme events of high CO. Therefore, there are occasional large differences between model results and the mean values of observations (e.g. at $350 \mathrm{hPa}$ on 18 July).

The difference of $\mathrm{CO}$ mixing ratios between the nobbNA simulation and other simulations, reflecting the contribution from North American biomass burning, is 10 20 ppbv, about $10 \%$ of the total CO (Fig. 9a). This enhancement occurs throughout the troposphere. The inclusion of North American biomass burning emissions improves the agreement with observations in the middle and upper troposphere while degrades the simulation in the lowermost troposphere.

The change of $\mathrm{CO}$ profile when using the MISRind injection height distribution is generally small. Note the synoptic lines in Fig. 9 are mostly overlapped with the MISRind lines. Even during days when the forest fires in Alaska and western Canada significantly increased the $\mathrm{CO}$ mixing ratios (as represented by the large difference between nobbNA and 

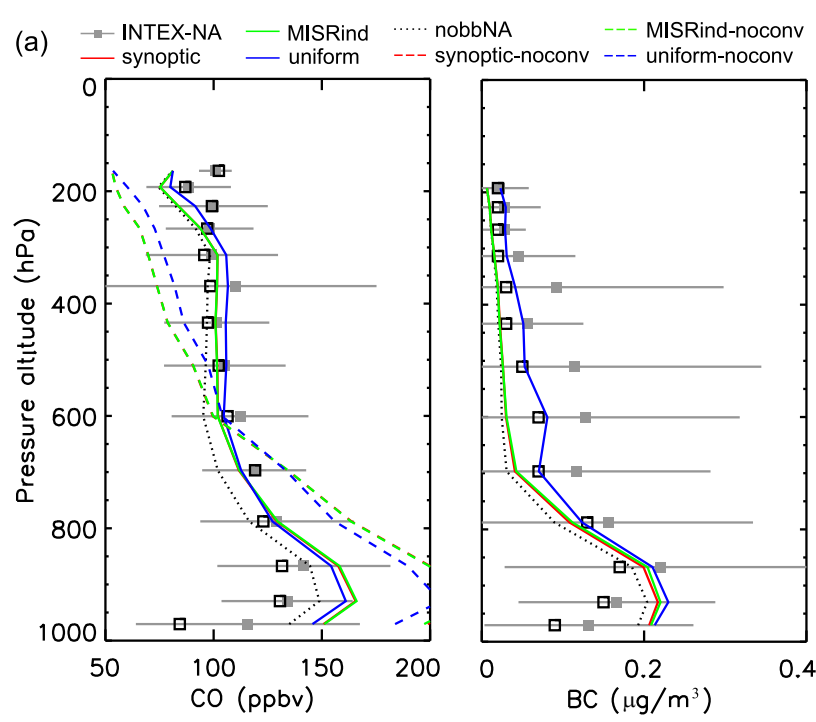

Fig. 9a. Comparisons of vertical $\mathrm{CO}$ and $\mathrm{BC}$ profiles from model simulations and from measurements during the 2004 INTEX-NA experiment for all flights. Grey points and bars are mean values and standard deviation of the observations at each level. Black squares are median values of the observations at each level. All model results are sampled along the flight trajectories.

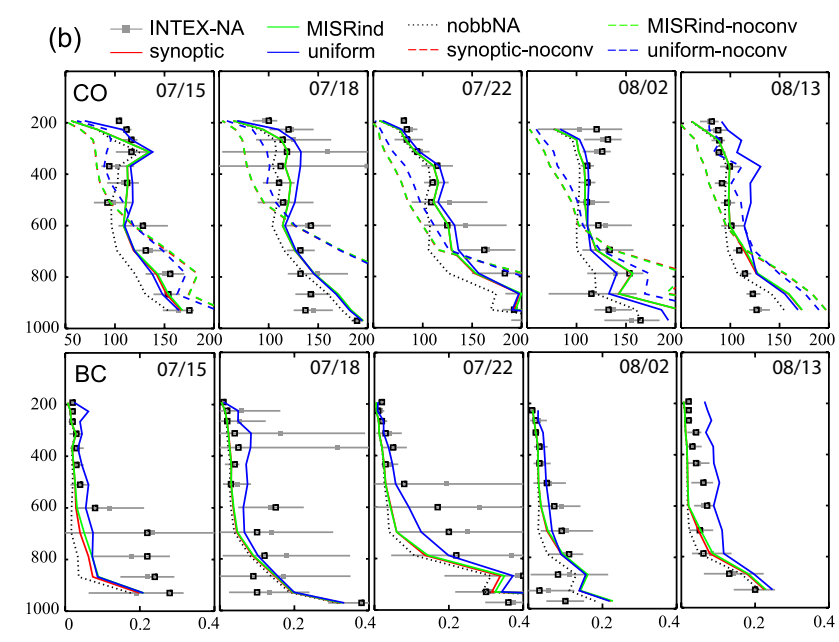

Fig. 9b. Same to Fig. 9a, but for representative individual flights.

synoptic $\mathrm{CO}$ profiles), the differences between the synoptic and MISRind profiles are almost negligible. It is not obvious from Fig. 9 that the uniform simulation improves the agreement with the aircraft observations in the upper troposphere, either in the average sense (left panel, Fig. 9a) or during individual flights (top row, Fig. 9b). It does show an enhanced plume in the upper troposphere during the flight on 15 July but significantly overestimates CO by more than 20 ppbv during the flight on 13 August.
The shape of $\mathrm{CO}$ profiles is determined by moist convection to a large degree. By turning off convection, GEOSChem significantly underestimates $\mathrm{CO}$ at high altitudes and overestimates $\mathrm{CO}$ at low altitudes. The model sensitivity to biomass burning injection height is also affected by convection. Most flights during INTEX-NA were thousands of kilometers away from the fire sources in Alaska and western Canada. During long-range transport, vertical mixing processes including convection carry more pollutants out of the PBL, thereby reducing the effect of biomass burning injection height. Figure 9 shows the difference between simulations with different injection height distributions is smaller when convection is turned on.

The vertical profile of $\mathrm{BC}$ is an important factor in determining BC radiative effect (Haywood and Ramaswamy, 1998; Penner et al., 2003). However, it is extremely difficult to compare the modeled BC vertical profile with measurements for several reasons. First, the data in each layer are more variable than for $\mathrm{CO}$ (shown with grey error bars in Fig. 9). Second, the assumed value of mass absorption efficiency, which is used to convert measured absorption extinction to $\mathrm{BC}$ concentration, may vary by more than a factor of two (Fuller et al., 1999; Andreae and Gelencsér, 2006). Third, the uncertainty caused by the deposition scheme used in the model may have a large impact on the comparison. Despite these uncertainties, the comparison (Fig. 9) shows small concentration differences between the synoptic and MISRind simulations.

\subsection{Comparison of modeled CO total column with MOPITT observations}

The MOPITT CO retrieval is most sensitive to the middle troposphere (Deeter et al., 2003). For direct comparison with MOPITT CO columns, GOES-Chem simulated CO profiles were sampled along MOPITT orbital tracks and then interpolated to the six standard MOPITT pressure levels and the surface. The resulting model profiles were then convolved with MOPITT averaging kernels and a priori profile (Emmons et al., 2004). To minimize the a priori influence and compare model results against actual measured information, we used MOPITT retrievals with a priori contributions less than a preset threshold. Two thresholds (50\% and 30\%) were used to show the sensitivity of the comparison to this value, as discussed below.

Figure 10 shows the 3-month (June-August 2004) average CO columns over North America from the MOPITT retrievals and from GEOS-Chem simulations. MOPITT CO shows high values over the fire source regions in Alaska and western Canada, over the west of Hudson Bay, and over eastern Canada. There is a significant difference between MOPITT and GEOS-Chem CO columns, both over the biomass burning source regions and downwind. Applying temporal constraints on biomass burning emissions improves the agreement between MOPITT and model CO columns in the 

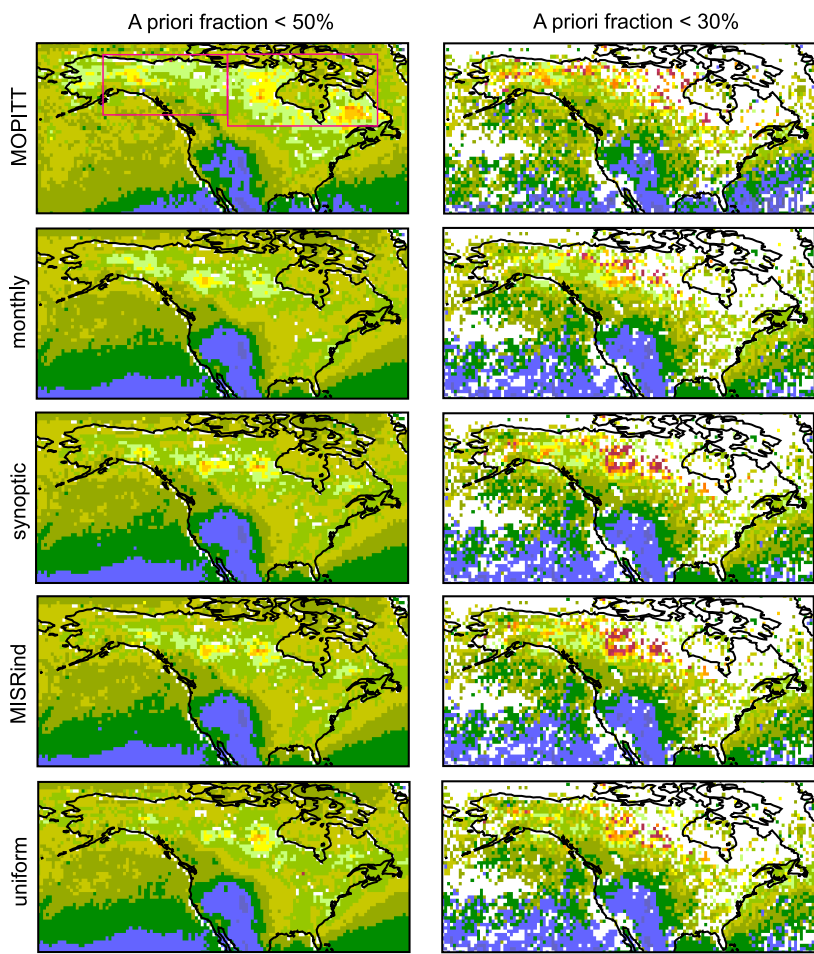

1.0 1.7

2.4

3.8
Fig. 10. Comparison of 3-month (June-August 2004) average CO column $\left(10^{18}\right.$ molec $\left./ \mathrm{cm}^{2}\right)$ from GEOS-Chem simulations and from MOPITT retrievals. MOPITT averaging kernel and the a priori CO profile were applied to model results. Two a priori critical fractions (50\% and $30 \%$ ) were used to filter out samples with large a priori contributions.

downwind region, where the correlation coefficient increases from 0.61 for the monthly to 0.69 for the synoptic. The use of MISRind and uniform injection height distributions decreases the CO column in the source regions, but they cause little change downwind. Over eastern Canada, the large discrepancy still exists when the temporal constraints are applied. Previous modeling studies have shown similar large model versus MOPITT CO column discrepancies and point to poor treatments of biomass burning emissions as a primary reason (Bian et al., 2007; Turquety et al., 2007). Our results show that even with a large portion of the fire emissions distributed in the middle and upper troposphere, as in the uniform simulation, the model still underestimates $\mathrm{CO}$ columns over this region. Therefore, the lack of fire emission injection above the PBL is unlikely to be the only or main cause of the large discrepancy. We should also bear in mind that the MOPITT measurement itself has uncertainty and bias. Emmons et al. (2004) showed that the MOPITT retrievals have an uncertainty of $20-40 \%$ at $500 \mathrm{hPa}$, and a bias of $-0.2 \%-8 \%$ compared to in situ $\mathrm{CO}$ measurements from aircraft.

Figure 10 also shows that the comparison is sensitive to the value of a priori critical fraction. The comparisons between model and MOPITT CO columns over the fire source regions are better when a priori critical fraction of $30 \%$ is used (correlation coefficient $R=0.54$ ), compared with $50 \%(R=0.46)$. Downwind, particularly over northeastern North America, fewer data samples satisfy the criterion of a priori fraction be less than $30 \%$, which makes the comparison more difficult. Our simulated CO column distribution (with a priori fraction $<50 \%$ ) is similar to that in Turquety et al. (2007), in which the same GEOS-Chem model with a different biomass burning emission inventory was used.

We further compare our model results with MOPITT retrievals by showing the time series of mean $\mathrm{CO}$ columns over a source domain $\left(150^{\circ}-110^{\circ} \mathrm{W}, 55^{\circ}-70^{\circ} \mathrm{N}\right)$ and a downwind domain $\left(110^{\circ}-60^{\circ} \mathrm{W}, 50^{\circ}-70^{\circ} \mathrm{N}\right)$ (Fig. 11). The domains are indicated in Fig. 10. Since MOPITT provides global coverage every 3 days, we used the 3-day average CO. Again, we applied two a priori critical fractions (50\% and 30\%).

The phase of temporal variability agrees well between MOPITT and all the GEOS-Chem simulations in the biomass burning source regions except the monthly. The correlation coefficient is considerably smaller in the monthly case $(R=0.08)$ than the other cases $(R>0.60)$. In general, the agreement is better in the source domain than in the downwind domain. Differences in magnitude between measurements and simulations are present, particularly during periods of major fire occurrences (represented by high emissions as shown in Fig. 11). For example, all model simulations underestimate CO columns in mid-July in the downwind domain, and overestimate $\mathrm{CO}$ in mid-August in both the source and downwind domains. This suggests that using MODIS fire counts to re-distribute biomass burning emissions may miss some important fire events (e.g. clouds may mask fire hot spots) and incorrectly represent the day-to-day variation.

The use of MISRind injection height distribution causes only small changes in the results. The uniform simulation produces smaller CO column in the source domain than the synoptic simulation, which sometimes shows better agreement with MOPITT but sometimes shows larger bias. The a priori critical fraction has a larger effect on the simulated $\mathrm{CO}$ column than on the MOPITT retrievals. Overall, the bias between model simulations and measurements is higher when we use a smaller critical fraction, partly due to the smaller number of data samples after applying the $30 \%$ restriction.

\subsection{Comparison of modeled results with surface aerosol and total AOD measurements}

Surface BC mass concentrations from model simulations and measurements at four IMPROVE sites are shown in Fig. 12. For each site, the upper panel shows the model sensitivity to biomass burning emission temporal distribution, whereas the lower panel shows the sensitivity to injection height distribution. Results from the diurnal and MISRpdf simulations 
(a) A priori fraction $<50 \%$

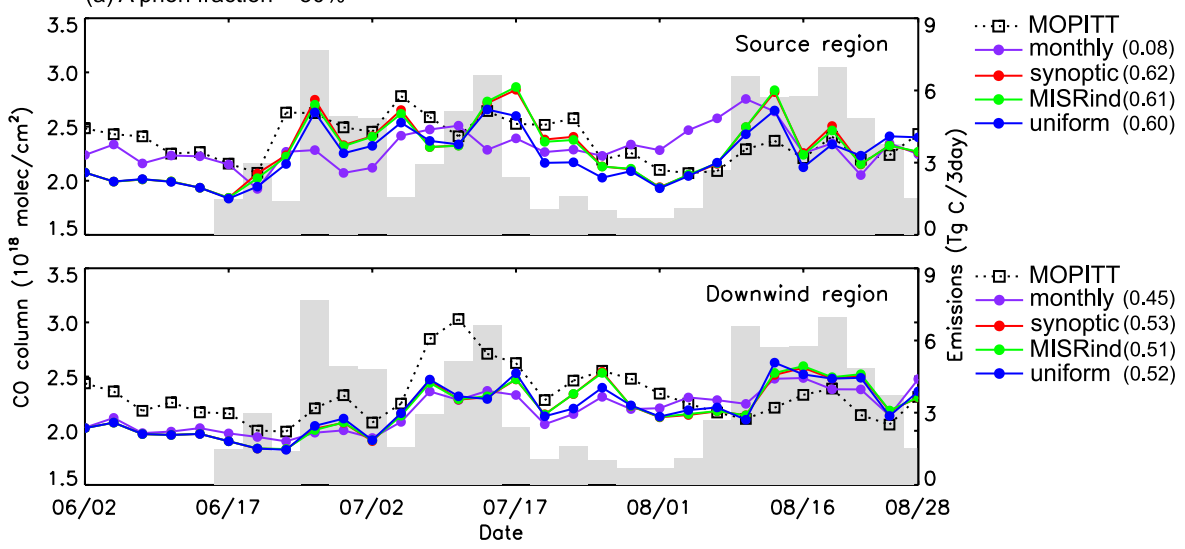

(b) A priori fraction $<30 \%$

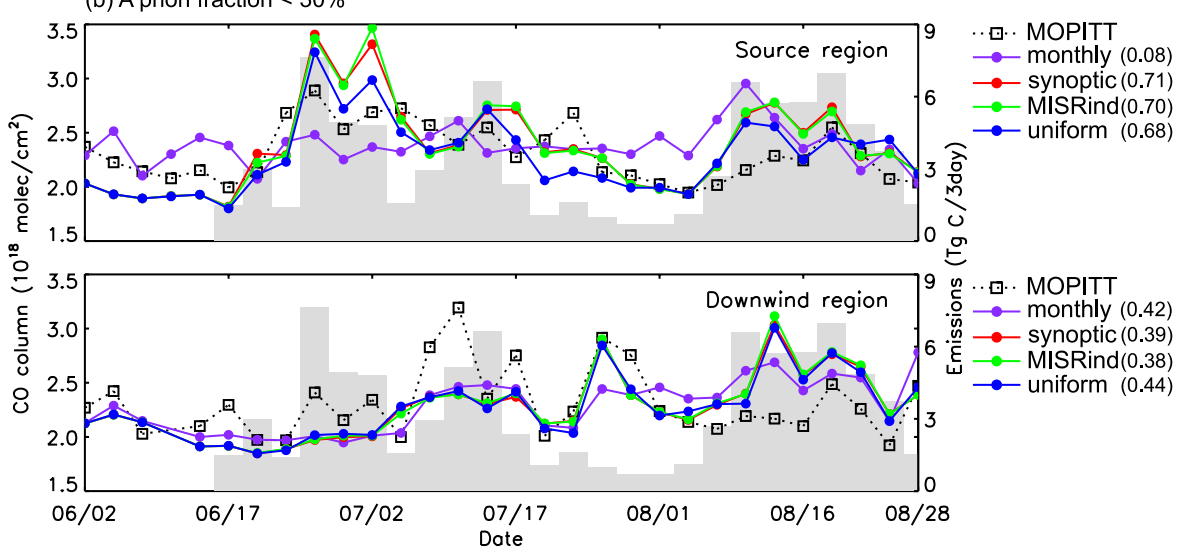

Fig. 11. Time series of mean CO column $\left(10^{18} \mathrm{molec} / \mathrm{cm}^{2}\right)$ in a source domain $\left(150^{\circ}-110^{\circ} \mathrm{W}, 55^{\circ}-70^{\circ} \mathrm{N}\right)$ and a downwind domain $\left(110^{\circ}-\right.$ $60^{\circ} \mathrm{W}, 50^{\circ}-70^{\circ} \mathrm{N}$ ) from MOPITT retrievals and GEOS-Chem simulations. Each point represents a value of three-day average CO column. Locations of these domains are shown in Fig. 10. MOPITT averaging kernel and the a priori CO profile were applied to model results. The correlation coefficients between MOPITT and model simulations are shown in the legend. Two a priori thresholds (50\% and 30\%) were used to filter out samples with large a priori contributions. Grey bars represent total biomass burning emissions (Tg C/3-day) in the domains.

are not shown, as they are very similar to the 8-day and MISRind simulations, respectively. Among the four IMPROVE sites, DENA1 $\left(63.7^{\circ} \mathrm{N}, 149.0^{\circ} \mathrm{W}\right)$ is very close to major fires. AMBL1 $\left(67.1^{\circ} \mathrm{N}, 157.9^{\circ} \mathrm{W}\right)$ is a Northern Alaskan site with no major fires, but is not far away from the major fire sources in Alaska and western Canada. MELA1 $\left(48.5^{\circ} \mathrm{N}\right.$, $\left.104.5^{\circ} \mathrm{W}\right)$ and BOWA1 $\left(47.9^{\circ} \mathrm{N}, 91.5^{\circ} \mathrm{W}\right)$ are near the USCanada border and are frequently affected by smoke from boreal fires in Alaska and western Canada.

We find the day-to-day variability in the model simulations resembles that from the IMPROVE measurements, except for the monthly simulation. This again indicates the importance of using emissions with at least an 8-day temporal resolution. The synoptic simulation, which includes both the diurnal cycle and the synoptic variability of biomass burning emissions, shows more temporal variability. But its effect on the comparison with measurements is smaller than switching from the monthly to the 8-day emissions. The use of
MISRind injection height distribution improves the simulation in the source region (DENA1 site) compared with no vertical injections, particularly during mid-July and late August. For the downwind sites, the $\mathrm{BC}$ surface concentrations from the MISRind simulation are similar to those from the synoptic simulation. The uniform simulation shows better agreement with IMPROVE measurements at the downwind sites. However, in the source region (DENA1 site), the uniform simulation often significantly underestimates surface BC. Therefore, high-elevation injection of biomass burning smoke injection might be episodic and possibly related to individual high-energy fire events and suitable meteorological conditions, or even high-energy fires might tend to inject a large fraction of smoke into the PBL than the uniform simulation assumes.

Figure 13 compares simulated time series of AOD at $500 \mathrm{~nm}$ with the AERONET retrievals in a source region site (Bonanza_Creak: $64.6^{\circ} \mathrm{N}, 148.3^{\circ} \mathrm{W}$ ) and three downwind 

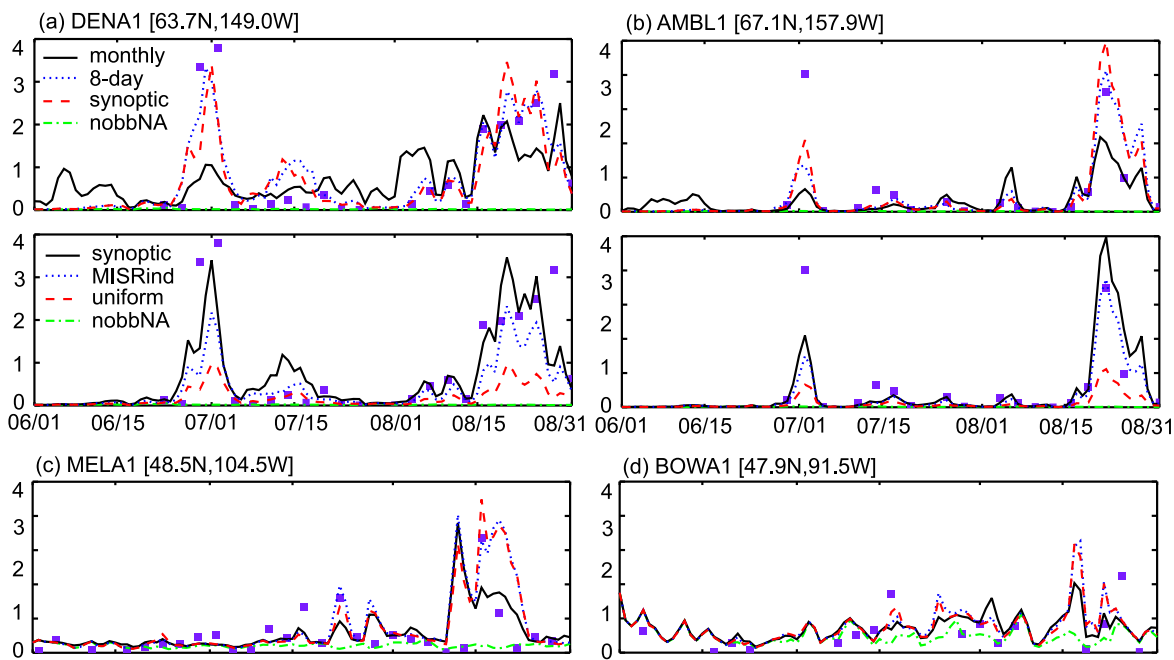

(d) BOWA1 [47.9N,91.5W]
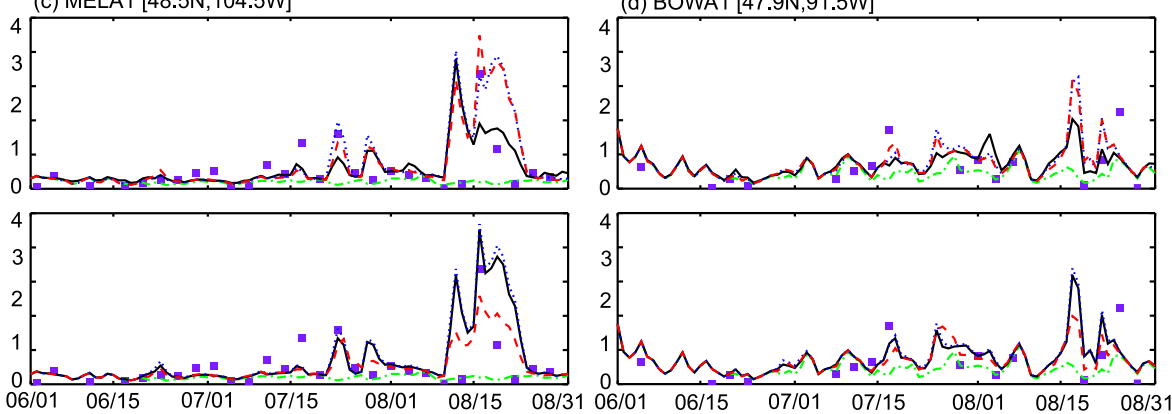

Fig. 12. Time series of surface $B C$ concentrations $\left(\mu \mathrm{g} / \mathrm{m}^{3}\right)$ from model simulations and IMPROVE observations (filled square boxes). IMPROVE measurements are $24 \mathrm{~h}$ average values which were recorded each 3 days. Upper panel for each site shows the sensitivity to temporal constraints. Bottom panel for each site shows the sensitivity to injection height.
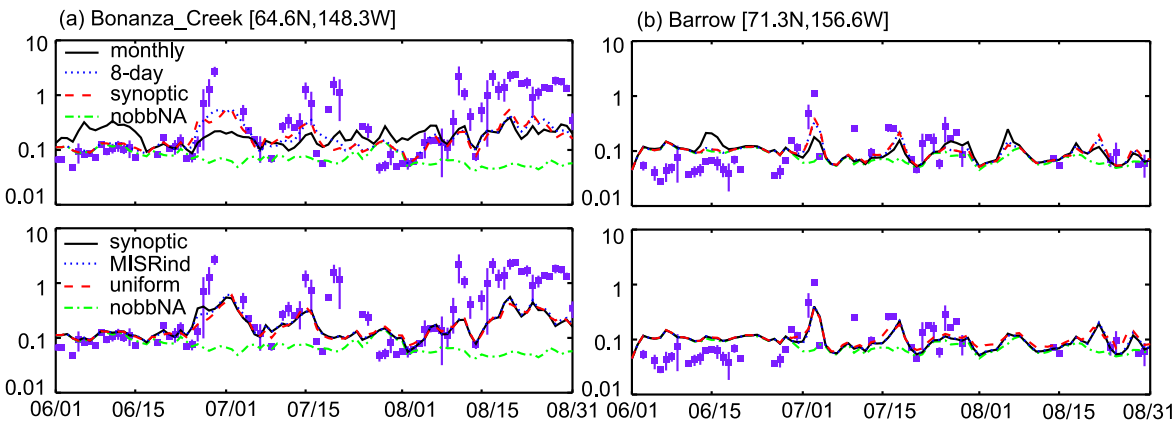

(c) Bratts_Lake $[50.3 \mathrm{~N}, 104.6 \mathrm{~W}]$

(d) Resolute Bay $[74.7 \mathrm{~N}, 94.9 \mathrm{~W}]$
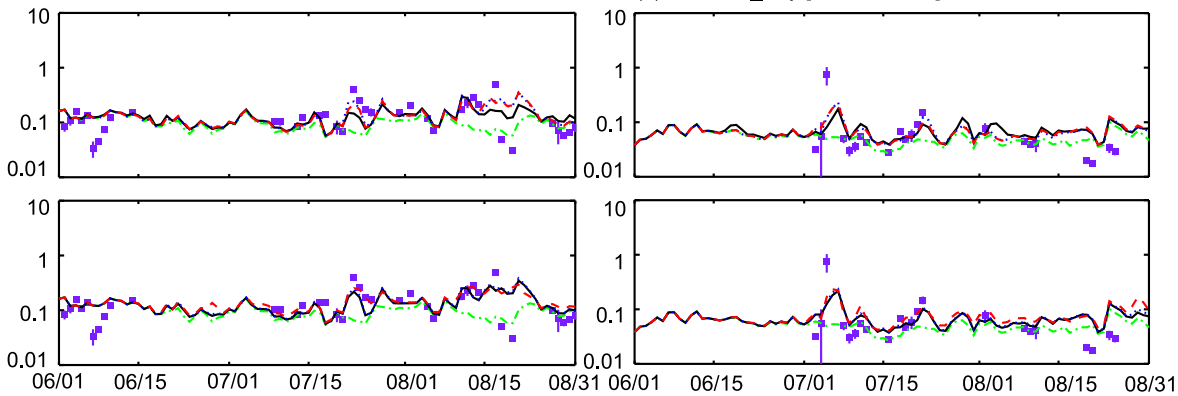

Fig. 13. Time series of $500 \mathrm{~nm}$ AOD from model simulations and AERONET observations. Daily mean values and uncertainty ranges of AERONET data are shown in filled square boxes and vertical bars. Upper panel for each site shows the sensitivity to temporal constraints. Bottom panel for each site shows the sensitivity to injection height. 
sites (Barrow; $71.3^{\circ} \mathrm{N}, 156.6^{\circ} \mathrm{W}$; Bratts_Lake; $50.3^{\circ} \mathrm{N}$, 104.6 $6^{\circ} \mathrm{W}$; Resolute_Bay; $74.7^{\circ} \mathrm{N}, 94.9^{\circ} \mathrm{W}$ ). We calculated total AODs from GEOS-Chem simulated aerosol concentrations and pre-assumed microphysical and optical properties associated with all aerosol species (Park et al., 2003). The use of 8-day temporal resolution and synoptic constraint improves the timing of high-AOD occurrences over both the source and downwind regions. For example, the correlation coefficients between observations and model results increased from 0.36 to 0.66 at Bonanza Creek and from 0.21 to 0.74 at Barrow. But there are still large discrepancies between simulated and AERONET AODs, particularly during high-AOD events. The nobbNA simulation produces very small AODs during these events, indicating a dominating contribution from North American biomass burning emissions. A comparison with satellite observed AODs from MISR and MODIS (not shown here) also shows the underestimation of GEOS-Chem model results. The low bias in the simulated AOD over biomass burning regions has been reported by several previous studies (Matichuk et al., 2007; Pfister et al., 2008). Pronounced spatiotemporal variability of AOD and different sampling between the measurements and the model may partly explain the discrepancy. The different assumptions of aerosol properties used in the satellite retrievals and model calculations may play a role as well. Recent studies of simulating directly satellite observed radiances in CTMs to retrieve AOD show better agreement between GEOS-Chem and MODIS (Drury et al., 2008). It avoids the aforementioned inconsistency. Figure 13 also shows the use of the MISRpdf and uniform injection height distributions only has minor change in the simulated AOD.

\section{Discussion}

Conflicting results have been reported in past work on the effect of fire-induced lifting in model simulations. Some comparisons between models and measurements (e.g. Leung et al., 2007; Freitas et al., 2006) show the best agreement when a large portion of fire emissions are injected into the middle troposphere. Turquety et al. (2007) concluded that a significant fraction of emissions from the largest fires should be injected into the upper troposphere in order to match MOPITT observations. Lamarque et al. (2003) and Colarco et al. (2004), however, showed that releasing of fire emissions at the surface may produce results similar to releasing emissions at high altitude, because in these models, local convection immediately lifts the pollution into the free troposphere.

Our results show that averaged over the 2004 summer fire season, the overall effect of using the MISR-derived injection height distribution is small. The change of simulated CO column by using MISRind distribution is smaller than $1 \%$ over most North America (Fig. 7). Compared to CO, the effect of injection height distribution on $\mathrm{BC}$ is larger, with $5 \%-10 \%$ increase in total column averaged over summer 2004 after
MISRind distribution being used. Both $\mathrm{CO}$ and $\mathrm{BC}$ changes due to the use of MISRind distribution are smaller than that caused by applying temporal constraints on biomass burning emissions. The combined effect of using the synoptic GFEDv2 and MISRind distribution can increase the mean BC burden over northeastern North America by $10 \%-20 \%$ (Fig. 7).

Previous studies (e.g. Turquety et al., 2007) have shown the use of higher injection heights may enhance the longrange transport of $\mathrm{CO}$ and reduce the bias between $\mathrm{CO}$ column derived from model simulation and MOPITT retrievals. Results from this study show that unlike the temporal constraints, which reduce the bias between modeled CO and MOPITT CO (Fig. 10), the injection height has little effect on the comparison. We believe that the lack of biomass burning injection heights above the PBL is unlikely the primary reason for the $\mathrm{CO}$ column underestimation over Quebec during 2004 summer. Other adjustments, such as improvements to total biomass burning emission amount, a better representation of emission temporal variability, and a more realistic meteorological field, may be more important.

On a shorter time scale, the injection height may have larger effects. Satellite-derived injection height distribution (MISRind) improves the agreement with surface measurements at or near the fire source (Fig. 12). But its effect on AOD is not significant (Fig. 13). We also notice the injection height effect is much smaller in the downwind region. The time series of CO column (Fig. 11), surface BC concentration (Fig. 12), and AOD (Fig. 13), and the vertical profiles of $\mathrm{CO}$ and BC (Fig. 9) over northeastern North America show very small difference between the synoptic and MISRind simulations. Even during large fire events, there is no conclusive evidence that the use of biomass burning emissions above the PBL will improve the simulation in the downwind region.

In Fig. 14, we take a fire event as an example to illustrate how the injection height effect is entangled with other uncertainties, particularly the meteorology driven transport. This fire event took place in mid-July 2004. High CO concentrations at $300 \mathrm{hPa}$ were observed by the DC- 8 aircraft during the INTEX-NA experiment on 18 July. We calculated backward air trajectories ending in Quebec (centered at $67^{\circ} \mathrm{W}$, $55^{\circ} \mathrm{N}$ ) at 19 July (00:00 UTC) using the HYbrid SingleParticle Lagrangian Integrated Trajectory (HYSPLIT) model (Draxler and Rolph, 2003; Rolph, 2003) and the NCAR re-analysis meteorology (Kalnay et al., 1996). This analysis shows that the enhancement of $\mathrm{CO}$ originated from fires in Alaska and western Canada around five days previously. The horizontal trajectory ending at $5 \mathrm{~km}$ above the ground is shown in Fig. 14a (from A to B). Most biomass burning emissions concentrate in the first half of this trajectory (Fig. 14b) during 13 15 July. As introduced in Sect. 5, we recorded the mixing ratios of tagged $\mathrm{CO}$ tracer from North American forest fire emissions (CObbNA). The CObbNA spatial distribution at $300 \mathrm{hPa}$ and its vertical profiles along the trajectory A-B from the synoptic simulation (with All_PBL injection 
(a)

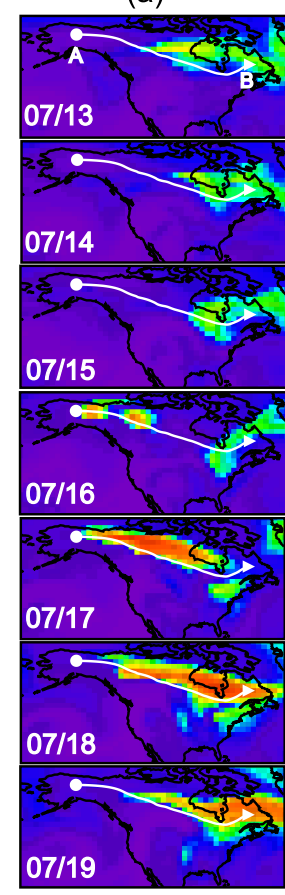

(b)

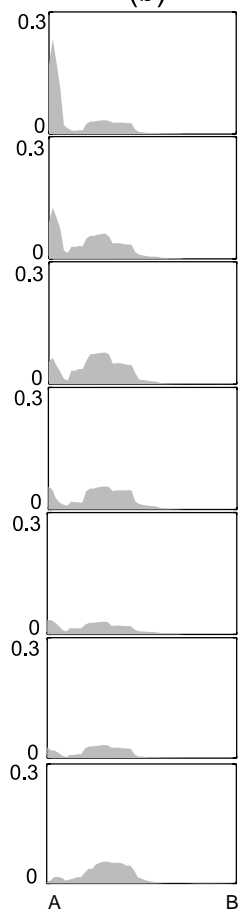

(c)

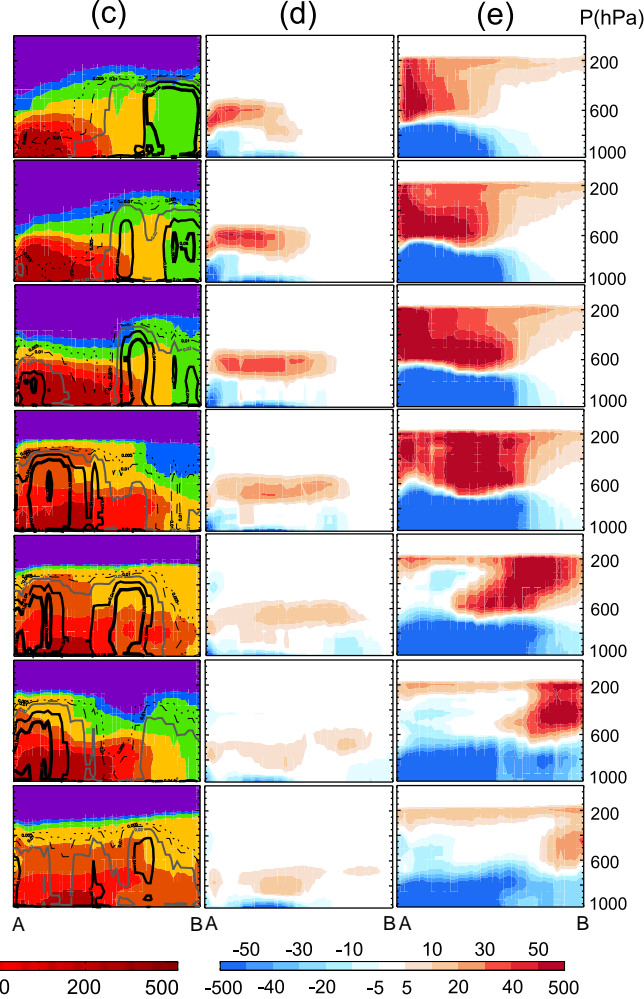

Fig. 14. Simulated daily mean CObbNA (CO from North American biomass burning source) during 13-19 July 2004. (a) CobbNA (ppbv) at $300 \mathrm{hPa}$ from the synoptic simulation. White line A-B is derived from the back trajectory analysis using the HYSPLIT model. The starting point $\mathrm{B}\left[55^{\circ} \mathrm{N}, 67^{\circ} \mathrm{W}\right]$ is located at $5 \mathrm{~km}$ above the ground level and the back trajectory starting time is 00:00 UTC, 19 July . (b) Total biomass burning emission rate ( $\mathrm{Tg} \mathrm{C} /$ month) in grid cells along the trajectory $\mathrm{A}-\mathrm{B}$. (c) CObbNA vertical profile along the trajectory A-B from the synoptic simulation. Line contours represent the deep convection mass flux $\left(\mathrm{kg} / \mathrm{m}^{2} / \mathrm{s}\right)$ from the GEOS- 4 reanalysis database. The contour levels are $0.005,0.01,0.02,0.04,0.06,0.1$ from light dashed line to thick solid line. (d) CObbNA difference along the trajectory A-B between the MISRind and synoptic simulations. (e) CObbNA difference along the trajectory A-B between the uniform and synoptic simulations.

height distribution) are shown in Fig. 14a and c. We also plot a contour of deep convective flux from the GEOS-4 meteorology over CO mixing ratio profiles in Fig. 14c. The horizontal and vertical patterns show the rise of fire emissions and the transport of $\mathrm{CO}$ from the source region near $\mathrm{A}$ to the downwind region near B. This rise and transport are closely related to meteorological conditions. During 13-15 July, despite large emissions in the source region, $\mathrm{CO}$ concentration in the upper troposphere is small. Strong deep convection from 16 July causes rapid mixing between the near-surface atmosphere and the upper troposphere. $\mathrm{CO}$ in the upper troposphere is then enhanced and transported to the downwind region. The differences of CObbNA profiles between the MISRind and synoptic simulations are shown in Fig. 14d. Since more emission is assigned to the middle troposphere in the MISRind distribution (see Fig. 3), an increase of $\mathrm{CO}$ between $400-600 \mathrm{hPa}$ and a decrease of CO in the PBL can be seen in Fig. 14d. During 13-15 July, when the convection is weak, this signal of injection height distribution is moved to the near downwind region (near the middle of $\mathrm{A}$ and B) without much abatement. However, this signal dissipates quickly after 16 July, likely due to the occurrence of strong convections near the fire sources.

The event shown in Fig. 14 is an example of how meteorology affects the influence of injection height. The use of MISRind injection height, which emulates the fast vertical transport due to the heat buoyancy and associated pyroconvection, does change the distribution of pollutants at or near the fire sources. However, the fraction of emissions above the PBL from the MISRind distribution is only about $15 \%$ of the total emissions. The effect caused by different injection height distributions for this fraction of emissions is easily dissipated by other vertical mixings. The case shown in Fig. 14 is not unique. It has been found that in high fire years in western Canada, a high-pressure system is often located above northwestern Canada and a low-pressure system above northeastern Canada (Skinner et al., 1999; Wotawa and Trainer, 2000). This climate pattern can cause strong convection in North America and can reduce the injection height effect of forest fires. 
Finally let us take a look at a special injection height distribution used in this study. The uniform distribution put more than $50 \%$ of the biomass burning emissions into the middle and upper troposphere. It appears that the injection height effect in this simulation can survive the strong vertical mixing and cause a significant enhancement downwind (Fig. 14). We find this uniform distribution may produce better results in the downwind region when compared with measurements during some fire events (e.g. CO mixing ratio at middle and high altitudes on 07/18 as shown in Fig. 9b, Surface BC concentration at MELA1 on 08/18 as shown in Fig. 12c). However, we note this injection height distribution is highly unrealistic. It simply assumes all biomass burning emissions follow the same distribution, neglecting the fact that high injection heights occur only at sporadic fire events when sufficient thermal buoyancy and appropriate atmospheric stability are available. As shown in previous sections, the use of the uniform injection height distribution may cause distorted vertical CO and BC profiles (e.g. on 08/13 as shown in Fig. 9b), and too low surface concentrations near the source (at DENA1 and AMBL1 as shown in Fig. 12), at least in some situations. The presence of some cases where the uniform simulation agrees better with the measurements than the MISRind simulation indicates that MISR observations may miss some high smoke injection events. This can be due to the limited spatial and temporal coverage of MISR radiance measurements, or the blocking of fire hot spots by clouds.

\section{Summary}

Aerosols and trace gases from boreal forest fires in Alaska and western Canada can be transported to eastern North America, the North Atlantic, and Europe, causing a degradation of air quality and influencing solar radiation and climate. Accurate estimation of this effect needs temporally and spatially resolved biomass burning emissions. We simulated $\mathrm{CO}$ and aerosols over North America during the 2004 fire season using the GEOS-Chem chemical transport model. We applied different temporal and injection height distributions to the biomass burning emissions, and evaluated model performance with these constraints by comparing the results with atmospheric measurements from multiple sources.

We find the use of finer temporal resolution biomass emissions usually decreases $\mathrm{CO}$ and $\mathrm{BC}$ near the fire source region, and often enhances long-range transport. Among the individual temporal constraints, switching from monthly to 8day GFEDv2 and including synoptic variability significantly affect $\mathrm{CO}$ and $\mathrm{BC}$ distributions. The monthly-to-8-day conversion often produces more southward transport. The inclusion of synoptic constraints is associated with stronger convection and more northward transport. Whether this shift of transport is a general phenomenon or is specific to this particular model environment for summer 2004 needs further investigation. The effect due to the diurnal cycle of biomass burning emissions is minimal.

Averaged over three months during summer 2004, the change of $\mathrm{CO}$ and $\mathrm{BC}$ due to the use of different injection height distributions is smaller than that due to the use of different temporal distributions. The model results are more sensitive to the biomass burning injection height near the source region. Allowing emissions above the PBL lowers surface concentrations and column burdens of pollutants near the source, whereas it increases pollutant concentrations at high altitude and downwind. But overall, the use of MISRderived injection height distribution increases $\mathrm{CO}$ burden in the downwind region only by less than $1 \%$. This is roughly consistent with Pfister et al. (2005), who showed that the CO fire emissions derived from inverse calculations are not sensitive to the vertical distribution of emissions.

The BC simulation is more sensitive to the temporal and injection height distributions of biomass burning emissions. The use of these constraints may increase the BC column in eastern North America by $10 \%-20 \%$. Over the whole US domain, the use of smoke injections above the PBL decreases the total $\mathrm{CO}$ burden but increases the $\mathrm{BC}$ burden. The shorter lifetime and smaller background concentration for $\mathrm{BC}$ are likely reasons for the contrasts between $\mathrm{CO}$ and $\mathrm{BC}$.

We compared our model results with $\mathrm{CO}$ and $\mathrm{BC}$ vertical profiles from INTEX-NA, the CO total column from MOPITT, surface BC concentrations from IMPROVE, and totalcolumn AOD from AERONET. These comparisons confirm the improvement when satellite data are used to constrain the intra-month variability. In particular, the use of 8-day GFEDv2 inventory shows much better agreement with most measurements than the monthly mean emissions.

In comparison to CO from MOPITT and BC from IMPROVE measurements, the use of MISR-derived injection height profile (MISRind) improves the simulation near the fire sources. The injection height effect is less apparent in the downwind regions. Modeled $\mathrm{CO}$ and $\mathrm{BC}$ vertical profiles closely match the INTEX-NA measurements over eastern North America, even when all the biomass burning emissions are distributed within the PBL. The discrepancies between model simulated and MOPITT retrieved CO over Quebec of Canada can not be simply attributed simply to the lack of biomass burning injections above the PBL. Neither the MISRind nor the uniform profile significantly reduces the disagreement. Reducing uncertainties from other sources, such as a better estimate of total burned area, a more realistic representation of emission temporal variability, or an improvement in moist convection parameterization, may do more to improve model performance.

The use of uniform injection height distribution occasionally improves the simulation during some fire events, which suggest the possible existence of high smoke injections. These high smoke injections could be missed by the MISR observations. But the uniform simulation often produces unrealistic results because it applies a fixed vertical 
distribution to all model grid boxes. For example, it often underestimates the surface concentrations in the source region and overestimates concentrations in upper troposphere by large fractions.

The change in $\mathrm{CO}$ vertical profiles due to different biomass burning emissions injection heights becomes smaller during transport. The dissipation of the injection height effect depends on meteorological conditions. The existence of strong convection during transport from Alaska and western Canada to northeastern North America often mixes the atmosphere between the PBL and free troposphere quickly, reducing the influence of injection heights.

Other than the temporal variability and injection height discussed in this study, the discrepancies between modeled and observed $\mathrm{CO}$ and $\mathrm{BC}$ may also be attributed to variability in fire emission factors. Emissions of $\mathrm{CO}$ and $\mathrm{BC}$ are very different during different stages of combustion, e.g. under smoldering and flaming conditions (Andreae and Merlet, 2001). Emissions factors are an important candidate for further study and may be constrained by combining satellite information on aerosol optical properties with $\mathrm{CO}$ measurements. In addition, the plume injection height may also have a diurnal cycle due to variations of fire power, surface energy fluxes, and atmospheric stability. Using MISR observations (with an approximately 10:30 a. m. local overpass time) to derive the plume height distribution is likely to underestimate the injections of pollutants in the free troposphere. However, accurate representation of these processes in the model remains challenging.

The simulations and comparisons shown in the present study only focus on North America during the summer of 2004. Although some conclusions (e.g. the improvement from monthly to 8-day simulations in reproducing measured termporal variability; the insensitivity to diurnal cycle of emissions) might generalize to other situations, different emission patterns and meteorological conditions may cause different model sensitivity to biomass burning temporal and injection height distributions over other regions and during other seasons. In addition, the current study describes the overall effect over North America during the whole summer. For some specific long-range transport events, the sensitivity to initial injection height distribution may be higher. Recently, MISR Plume Height Climatology Project has produced a smoke injection height climatology over North America for the years 2002 and 2004-2007. This dataset will enable us to use variable injection height distributions over different fire period.

Acknowledgements. The work is performed at the Jet Propulsion Laboratory, under contract with NASA. We gratefully acknowledge the NOAA Air Resources Laboratory (ARL) for the provision of the HYSPLIT transport and dispersion model and/or READY website (http://www.arl.noaa.gov/ready.html) used in this publication. Yang Chen is supported partly by the MISR project and the NASA Atmospheric Chemistry Modeling and Analysis Program (ACMAP). Qinbin Li is in part supported by
ACMAP. James T. Randerson is grateful for support from NASA (NNX08AF64G) for the development of GFED. The GEOS-Chem model is managed by the Atmospheric Chemistry Modeling group at Harvard University with support from the NASA Atmospheric Chemistry Modeling and Analysis Program.

Edited by: B. N. Duncan

\section{References}

Andreae, M. O. and Gelencsér, A.: Black carbon or brown carbon? The nature of light-absorbing carbonaceous aerosols, Atmos. Chem. Phys., 6, 3131-3148, 2006, http://www.atmos-chem-phys.net/6/3131/2006/.

Andreae, M. and Merlet, P.: Emission of trace gases and aerosols from biomass burning, Global Biogeochem. Cy., 15, 955-966, 2001.

Balkanski, Y., Jacob, D. J., Gardner, G. M., Graustein, W. C., and Turekian, K. K.: Transport and residence times of tropospheric aerosols from a global three-dimensional simulation of $210 \mathrm{~Pb}$, J. Geophys. Res., 98(D11), 20573-20586, 1993.

Bey, I., Jacob, D. J., Yantosca, R. M., Logan, J. A., Field, B. D., Fiore, A. M., Li, Q., Liu, H. Y., Mickley, L. J., and Schultz, M. G.: Global modeling of tropospheric chemistry with assimilated meteorology: Model description and evaluation, J. Geophys. Res., 106(D19)), 23073-23095, 2001.

Bian, H., Chin, M., Kawa, S. R., Duncan, B., Arellano, A., and Kasibhatla, P.: Sensitivity of global CO simulations to uncertainties in biomass burning sources, J. Geophys. Res., 112, D23308, doi:10.1029/2006JD008376, 2007.

Bond, T. C. and Bergstrom, R. W.: Light absorption by carbonaceous particles: An investigative review, Aerosol. Sci. Tech., 39, 1-41, 2005.

Cahoon, Jr., D. R., Stocks, B. J., Levine, J. S., Cofer, III, W. R., and O'Neill, K. P.: Seasonal distribution of African savanna fires, Nature, 359, 812-815, 1992.

Chow, J. C. and Watson, J. G.: $\mathrm{PM}_{2.5}$ carbonate concentrations at regionally representative Interagency Monitoring of Protected Visual Environment sites, J. Geophys. Res., 107(D21), 8344, doi:10.1029/2001JD000574, 2002.

Colarco, P. R., Schoeberl, M. R., Doddridge, B. G., Marufu, L. T., Torres, O., and Welton, E. J.: Transport of smoke from Canadian forest fires to the surface near Washington, D. C.: Injection height, entrainment, and optical properties, J. Geophys. Res., 109, D06203, doi:10.1029/2003JD004248, 2004.

Cook, P. A., Savage, N. H., Turquety, S., et al.: Forest fire plumes over the North Atlantic: p-TOMCAT model simulations with aircraft and satellite measurements from the ITOP/ICARTT campaign, J. Geophys. Res., 112, D10S43, doi:10.1029/2006JD007563, 2007.

Cooke, W. F., Liousse, C., Cachier, H., and Feichter, J.: Construction of a $1^{\circ} \times 1^{\circ}$ fossil fuel emission data set for carbonaceous aerosol and implementation and radiative impact in the ECHAM4 model, J. Geophys. Res., 104(D18), 22137-22162, 1999.

Deeter, M. N., Emmons, L. K., Francis, G. L., et al.: Operational carbon monoxide retrieval algorithm and selected results 
for the MOPITT instrument, J. Geophys. Res., 108(D14), 4399, doi:10.1029/2002JD003186, 2003.

Draxler, R. R. and Rolph, G. D.: HYSPLIT (HYbrid Single-Particle Lagrangian Integrated Trajectory) Model access via NOAA ARL READY Website (http://www.arl.noaa.gov/ready/hysplit4.html), last access: 1 September 2009, NOAA Air Resources Laboratory, Silver Spring, MD, 2003.

Drummond, J. R. and Mand, G. S.: The measurements of pollution in the troposphere (MOPITT) instrument: Overall performance and calibration requirements, J. Atmos. Ocean. Tech., 13, 314320, 1996

Drury, E., Jacob, D. J., Wang, J., Spurr, R. J. D., and Chance, K.: Improved algorithm for MODIS satellite retrievals of aerosol optical depths over western North America, J. Geophys. Res., 113, D16204, doi:10.1029/2007JD009573, 2008.

Duck, T. J., Firanski, B. J., Millet, D. B., et al.: Transport of forest fire emissions from Alaska and the Yukon Territory to Nova Scotia during summer 2004, J. Geophys. Res., 112, D10S44, doi:10.1029/2006JD007716, 2007.

Duffy, P. A., Walsh, J. E., Graham, J. M., Mann, D. H., and Rupp, T. S.: Impacts of large-scale atmospheric-ocean variability on alaskan fire season severity, Ecol. Appl., 15(4), 13171330, 2005.

Duncan, B. N., Martin, R. V., Staudt, A. C., Yevich, R., and Logan, J. A.: Interannual and Seasonal Variability of Biomass Burning Emissions Constrained by Satellite Observations, J. Geophys. Res., 108(D2), 4040, doi:10.1029/2002JD002378, 2003.

Emmons, L. K., Deeter, M. N., Gille, J. C., et al.: Validation of Measurements of Pollution in the Troposphere (MOPITT) CO retrievals with aircraft in situ profiles, J. Geophys. Res., 109, D03309, doi:10.1029/2003JD004101, 2004.

Eva, H. and Lambin, E. F.: Remote sensing of biomass burning in tropical regions: Sampling issues and multisensor approach, Remote Sens. Environ., 64, 292-315, 1998.

Flanner, M. G., Zender, C. S., Randerson, J. T., and Rasch, P. J.: Present-day climate forcing and response from black carbon in snow, J. Geophys. Res., 112, D11202, doi:10.1029/2006JD008003, 2007.

Forster, P., Ramaswamy, V., Artaxo, P., Berntsen, T., Betts, R., Fahey, D. W., Haywood, J., Lean, J., Lowe, D. C., Myhre, G., Nganga, J., Prinn, R., Raga, G., Schulz, M. and Van Dorland, R.: Changes in atmospheric constituents and in radiative forcing, in: Climate Change 2007: The Physical Science Basis, Contribution of Working Group I to the Fourth Assessment Report of the Intergovernmental Panel on Climate Change, edited by: Solomon, S., Qin, D., Manning, M., Chen, Z., Marquis, M., Averyt, K. B., Tignor, M. and Miller, H. L., Cambridge University Press, Cambridge, UK and New York, NY, USA, 2007.

Forster, C., Wandinger, U., Wotawa, G., et al.: Transport of boreal forest fire emissions from Canada to Europe, J. Geophys. Res., 106, D19, 22887-22906, 2001.

Freitas, S. R., Longo, K. M., and Andreae, M. O.: Impact of including the plume rise of vegetation fires in numerical simulations of associated atmospheric pollutants, Geophys. Res. Lett., 33, L17808, doi:10.1029/2006GL026608, 2006.

Freitas, S. R., Longo, K. M., Chatfield, R., Latham, D., Silva Dias, M. A. F., Andreae, M. O., Prins, E., Santos, J. C., Gielow, R., and Carvalho Jr., J. A.: Including the sub-grid scale plume rise of vegetation fires in low resolution atmospheric transport models,
Atmos. Chem. Phys., 7, 3385-3398, 2007, http://www.atmos-chem-phys.net/7/3385/2007/.

Fromm, M., Bevilacqua, R., Servranckx, R., Rosen, J., Thayer, J. P., Herman, J., and Larko, D.: Pyro-cumulonimbus injection of smoke to the stratosphere: Observations and impact of a super blowup in northwestern Canada on 3-4 August 1998, J. Geophys. Res., 110, D08205, doi:10.1029/2004JD005350, 2005.

Fuller, K. A., Malm, W. C., and Kreidenweis, S. M.: Effects of mixing on extinction by carbonaceous particles, J. Geophys. Res., 104(D13), 15941-15954, 1999.

Giglio, L., Descloitres, J., Justice, C. O., and Kaufman, Y.: An enhanced contextual fire detection algorithm for MODIS, Remote Sens. Environ., 87, 273-282, 2003.

Giglio, L., van der Werf, G. R., Randerson, J. T., Collatz, G. J., and Kasibhatla, P.: Global estimation of burned area using MODIS active fire observations, Atmos. Chem. Phys., 6, 957-974, 2006, http://www.atmos-chem-phys.net/6/957/2006/.

Giglio, L.: Characterization of the tropical diurnal fire cycle using VIRS and MODIS observations, Remote Sens. Environ., 108, 407-421, 2007.

Gillett, N. P., Weaver, A. J., Zwiers, F. W., and Flannigan, M. D.: Detecting the effect of climate change on Canadian forest fires, Geophys. Res. Lett., 31, L18211, doi:10.1029/2004GL020876, 2004.

Goode, J. G., Yokelson, R. J., Ward, D. E., Susott, R. A., Babbitt, R. E., Davies, M. A., and Hao, W. M.: Measurements of excess $\mathrm{O}_{3}, \mathrm{CO}_{2}, \mathrm{CO}, \mathrm{CH}_{4}, \mathrm{C}_{2} \mathrm{H}_{4}, \mathrm{C}_{2} \mathrm{H}_{2}, \mathrm{HCN}, \mathrm{NO}, \mathrm{NH}_{3}$, $\mathrm{HCOOH}, \mathrm{CH}_{3} \mathrm{COOH}, \mathrm{HCHO}$, and $\mathrm{CH}_{3} \mathrm{OH}$ in 1997 Alaskan biomass burning plumes by airborne Fourier transform infrared spectroscopy (AFTIR), J. Geophys. Res., 105(D17), 2214722166, 2000.

Hack, J. J.: Parameterization of moist convection in the National Center for Atmospheric Research community climate model (CCM2), J. Geophys. Res., 99(D3), 5551-5568, 1994.

Hansen, J. and Nazarenko, L.: Soot climate forcing via snow and ice albedos, P. Natl. Acad. Sci. USA, 101, 423-428, doi:10.1073/pnas.2237157100, 2004.

Haywood, J. M. and Ramaswamy, V.: Global sensitivity studies of the direct forcing due to anthropogenic sulfate and black carbon aerosols, J. Geophys. Res., 103, 6043-6058, 1998.

Heald, C. L., Jacob, D. J., Jones, D. B. A., Palmer, P. I., Logan, J. A., Streets, D. G., Sachse, G. W., Gille, J. C., Hoffman, R. N., and Nehrkorn, T.: Comparative inverse analysis of satellite (MOPITT) and aircraft (TRACE-P) observations to estimate Asian sources of carbon monoxide, J. Geophys. Res., 109, D23306, doi:10.1029/2004JD005185, 2004.

Holben, B. N., Eck, T. F., Slutsker, I., Tanre, D., Buis, J. P., Setzer, A., Vermote, E. F., Reagan, J. A., Kaufman, Y. J., Nakajima, T., Lavenu, F., Jankowiak, I., and Smirnov, A.: AERONET - A federated instrument network and data archive for aerosol characterization, Remote Sens. Environ., 66(1), 1-16, 1998.

Horvath, H.: Atmospheric light absorption - a review, Atmos. Environ., 27A, 293-317, 1993.

Hudman, R. C., Jacob, D. J., Cooper, O. R., et al.: Ozone production in transpacific Asian pollution plumes and implications for ozone air quality in California, J. Geophys. Res., 109, D23S10, doi:10.1029/2004JD004974, 2004.

Hudman, R. C., Jacob, D. J., Turquety, S., et al.: Surface and lightning sources of nitrogen oxides over the United States: Magni- 
tudes, chemical evolution, and outflow, J. Geophys. Res., 112, D12S05, doi:10.1029/2006JD007912, 2007.

Hyer, E. J., Kasischke, E. S., and Allen, D. J.: Effects of source temporal resolution on transport simulations of boreal fire emissions, J. Geophys. Res., 112, D01302, doi:10.1029/2006JD007234, 2007.

Jacob, D. J., Liu, H., Mari, C., and Yantosca, R. M.: Harvard wet deposition scheme for GMI, Harvard Atmospheric Chemistry Modeling Group, available at: http://gmi.gsfc.nasa.gov/models/ jacob_wetdep.pdf, last access: 1 September 2009, 2000.

Kahn, R. A., Li, W.-H., Moroney, C., Diner, D. J., Martonchik, J. V., and Fishbein, E.: Aerosol source plume physical characteristics from space-based multiangle imaging, J. Geophys. Res., 112, D11205, doi:10.1029/2006JD007647, 2007.

Kahn, R. A., Chen, Y., Nelson, D. L., Leung, F.-Y., Li, Q., Diner, D. J., Logan, J. A.: Wildfire smoke injection heights: Two perspectives from space, Geophys. Res. Lett., 35, L04809, doi:10.1029/2007GL032165, 2008.

Kalnay, E., Kanamitsu, M., Kistler, R., Collins, W., Deaven, D., Gandin, L., Iredell, M., Saha, S., White, G., Woollen, J., Zhu, Y., Leetmaa, A., Reynolds, R., Chelliah, M., Ebisuzaki, W., Higgins, W., Janowiak, J., Mo, K., Ropelewski, C., Wang, J., Jenne, R., and Joseph, D.: The NCEP/NCAR 40-Year Reanalysis Project, B. Am. Meteorol. Soc., 77, 437-471, 1996.

Kasischke, E. S., Hyre, E. P., Novelli, P. C., Bruhwiler, L. P., French, N. H. F., Sukhinin, A., Hewson, J., and Stocks, B. J.: Influences of boreal fire emissions on Northern Hemisphere atmospheric carbon and carbon monoxide, Global Biogeochem. Cy., 19, GB1012, doi:10.1029/2004GB002300, 2005.

Kasischke, E. S. and Turetsky, M. R.: Recent changes in the fire regime across the North American boreal region - Spatial and temporal patterns of burning across Canada and Alaska, Geophys. Res. Lett., 33, L09703, doi:10.1029/2006GL025677, 2006.

Labonne, M., Breon, F.-M., and Chevallier, F.: Injection height of biomass burning aerosols as seen from a spaceborne lidar, Geophys. Res. Lett., 34, L11806, doi:10.1029/2007GL029311, 2007.

Lamarque, J.-F., Edwards, D. P., Emmons, L. K., et al.: Identification of $\mathrm{CO}$ plumes from MOPITT data: Application to the August 2000 Idaho-Montana forest fires, Geophys. Res. Lett., 30(13), 1688, doi:10.1029/2003GL017503, 2003.

Langaas, S.: Temporal and spatial distribution of savanna fires in Senegal and The Gambia, West Africa, 1989-1990, derived from multi-temporal AVHRR night images, Int. J. Wildland Fire, 2(1), 21-36, 1992.

Lavoué, D., Liousse, C., Cachier, H., Stocks, B., and Goldammer, J.: Modeling of carbonaceous particles emitted by boreal and temperate wildfires at northern latitudes, J. Geophys. Res., 105(D22), 26871-26890, 2000.

Leung, F.-Y. T., Logan, J. A., Park, R., Hyer, E., Kasischke, E., Streets, D., and Yurganov, L.: Impacts of enhanced biomass burning in the boreal forests in 1998 on tropospheric chemistry and the sensitivity of model results to the injection height of emissions, J. Geophys. Res., 112, D10313, doi:10.1029/2006JD008132, 2007.

Lin, S. J. and Rood, R. B.: Multidimensional flux-form semiLagrangian transport schemes, Mon. Weather Rev., 124(9), 2046-2070, 1996.

Liu, H., Jacob, D. J., Bey, I., and Yantosca, R. M.: Constraints from ${ }^{210} \mathrm{~Pb}$ and ${ }^{7} \mathrm{Be}$ on wet deposition and transport in a global three- dimensional chemical tracer model driven by assimilated meteorological fields, J. Geophys. Res., 106(D11), 12109-12128, 2001.

Luderer, G., Trentmann, J., Winterrath, T., Textor, C., Herzog, M., Graf, H. F., and Andreae, M. O.: Modeling of biomass smoke injection into the lower stratosphere by a large forest fire (Part II): sensitivity studies, Atmos. Chem. Phys., 6, 5261-5277, 2006, http://www.atmos-chem-phys.net/6/5261/2006/.

Matichuk, R. I., Colarco, P. R., Smith, J. A., and Toon, O. B.: Modeling the transport and optical properties of smoke aerosols from African savanna fires during the Southern African Regional Science Initiative campaign (SAFARI 2000), J. Geophys. Res., 112, D08203, doi:10.1029/2006JD007528, 2007.

Menzel, W. P. and Prins, E. M.: Monitoring biomass burning with the new generation of geostationary satellites, edited by: Levine, J. S., in: Biomass burning and global change: Remote sensing, modeling and inventory development, and biomass burning in Africa, Cambridge:MIT press, 1, 56-64, 1996.

Moroney, C., Davies, R., and Muller, J.-P.: MISR stereoscopic image matchers: Techniques and results, IEEE T. Geosci. Remote, 40, 1547-1559, 2002.

Naud, C., Muller, J.-P., Clothiaux, E. E., Baum, B. A., and Menzel, W. P.: Intercomparison of multiple years of MODIS, MISR, and radar cloud-top heights, Ann. Geophys., 23, 2415-2424., 2005.

Nelson, D. L., Chen, Y., Kahn, R. A., Diner, D. J., and Mazzoni, D.: Example applications of the MISR Interactive eXplorer (MINX) software tool to wildfire smoke plume analyses, Proceedings of SPIE Optics and Photonics, San Diego, CA, 2008.

Nicholson, K. W.: The dry deposition of small particles: A review of experimental measurements, Atmos. Environ., 22(12), 26532666, 1988.

Pack, D. W., Rice, C. J., Tressel, B. J., Lee-Wagner, C. J., and Oshika, E. M.: Civilian uses of surveillance satellites, Crosslink, 1(1), 2-8, 2000.

Park, R. J., Jacob, D. J., Chin, M., and Martin, R. V.: Sources of carbonaceous aerosols over the United States and implications for natural visibility, J. Geophys. Res., 108(D12), 4355, doi:10.1029/2002JD003190, 2003.

Park, R. J., Jacob, D. J., Field, B. D., Yantosca, R. M., and Chin, M.: Natural and transboundary pollution influences on sulfate-nitrate-ammonium aerosols in the United States: Implications for policy, J. Geophys. Res., 109, D15204, doi:10.1029/2003JD004473, 2004.

Penner, J. E., Zhang, S. Y., and Chuang, C. C.: Soot and smoke aerosol may not warm climate, J. Geophys. Res., 108(D21), 4657, doi:10.1029/2003JD003409, 2003.

Pfister, G., Hess, P. G., Emmons, L. K., Lamarque, J.-F., Wiedinmyer, C., Edwards, D. P., Pétron, G., Gille, J. C., and Sachse, G. W.: Quantifying CO emissions from the 2004 Alaskan wildfires using MOPITT CO data, Geophys. Res. Lett., 32, L11809, doi:10.1029/2005GL022995, 2005.

Pfister, G. G., Hess, P. G., Emmons, L. K., Rasch, P. J., and Vitt, F. M.: Impact of the summer 2004 Alaska fires on top of the atmosphere clear-sky radiation fluxes, J. Geophys. Res., 113, D02204, doi:10.1029/2007JD008797, 2008.

Prins, E., Feltz, J., Menzel, W., and Ward, D.: An overview of GOES-8 diurnal fire and smoke results for SCAR-B and 1995 fire season in South America, J. Geophys. Res., 103(D24), 3182131835, 1998. 
Real, E., Law, K. S., Weinzierl, B., et al.: Processes influencing ozone levels in Alaskan forest fire plumes during longrange transport over the North Atlantic, J. Geophys. Res., 112, D10S41, doi:10.1029/2006JD007576, 2007.

Rolph, G. D.: Real-time Environmental Applications and Display sYstem (READY) Website (http://www.arl.noaa.gov/ ready/hysplit4.html), last access: 1 September 2009, NOAA Air Resources Laboratory, Silver Spring, MD, 2003.

Sander, S. P., Friedl, R. R., DeMore, W. B., et al.: Chemical kinetics and photochemical data for use in stratospheric modeling, Evaluation number 13, JPL Publ. 00-3, Jet Propul. Lab., Pasadena, Calif., 2000.

Singh, H. B., Brune, W. H., Crawford, J. H., Jacob, D. J., and Russell, P. B: Overview of the summer 2004 Intercontinental Chemical Transport Experiment - North America (INTEX-A), J. Geophys. Res., 111, D24S01, doi:10.1029/2006JD007905, 2006.

Skinner, W. R., Stocks, B. J., Martell, D. L., Bonsal, B., and Shabbar, A.: The association between circulation anomalies in the mid-troposphere and area burned by wildland fire in Canada, Theor. Appl. Climatol., 63, 89-105, 1999.

Smirnov, A., Holben, B. N., Eck, T. F., Dubovik, O., and Slutsker, I.: Cloud screening and quality control algorithms for the AERONET database, Remote Sens. Environ., 73, 337-349, 2000.

Stohl, A., Andrews, E., Burkhart, J. F., et al.: Pan-Arctic enhancements of light absorbing aerosol concentrations due to North American boreal forest fires during summer 2004, J. Geophys. Res., 111, D22214, doi:10.1029/2006JD007216, 2006.

Stone, R. S., Anderson, G. P., Shettle, E. P., Andrews, E., Loukachine, K., Dutton, E. G., Schaaf, C., and Roman III, M. O.: Radiative impact of boreal smoke in the Arctic: Observed and modeled, J. Geophys. Res., 113, D14S16, doi:10.1029/2007JD009657, 2008.

Textor, C., Schulz, M., Guibert, S., Kinne, S., Balkanski, Y., Bauer, S., Berntsen, T., Berglen, T., Boucher, O., Chin, M., Dentener, F., Diehl, T., Feichter, J., Fillmore, D., Ginoux, P., Gong, S., Grini, A., Hendricks, J., Horowitz, L., Huang, P., Isaksen, I. S. A., Iversen, T., Kloster, S., Koch, D., Kirkevåg, A., Kristjansson, J. E., Krol, M., Lauer, A., Lamarque, J. F., Liu, X., Montanaro, V., Myhre, G., Penner, J. E., Pitari, G., Reddy, M. S., Seland, Ø., Stier, P., Takemura, T., and Tie, X.: The effect of harmonized emissions on aerosol properties in global models - an AeroCom experiment, Atmos. Chem. Phys., 7, 4489-4501, 2007, http://www.atmos-chem-phys.net/7/4489/2007/.
Trentmann, J., Andreae, M. O., Graf, H.-F., Hobbs, P. V., Ottmar, R. D., and Trautmann, T.: Simulation of a biomass burning plume: Comparison of model results with observations: J. Geophys. Res., 107, 4013, doi:10.1029/2001JD000410, 2002.

Trentmann, J., Luderer, G., Winterrath, T., Fromm, M. D., Servranckx, R., Textor, C., Herzog, M., Graf, H.-F., and Andreae, M. O.: Modeling of biomass smoke injection into the lower stratosphere by a large forest fire (Part I): reference simulation, Atmos. Chem. Phys., 6, 5247-5260, 2006, http://www.atmos-chem-phys.net/6/5247/2006/.

Turquety, S., Logan, J. A., Jacob, D. J., et al.: Inventory of boreal fire emissions for North America in 2004: Importance of peat burning and pyroconvective injection, J. Geophys. Res., 112, D12S03, doi:10.1029/2006JD007281, 2007.

Val Martin, M., Logan, J., Kahn, R., Leung, F.-Y., Nelson, D., and Diner, D.: Smoke injection heights from fires in North America: Analysis of 5 years of satellite observations, submitted to ACPD, 2009.

Van der Werf, G. R., Randerson, J. T., Collatz, G. J., and Giglio, L.: Carbon emissions from fires in tropical and subtropical ecosystems, Global Change Biol., 9, 547-562, 2003.

van der Werf, G. R., Randerson, J. T., Giglio, L., Collatz, G. J., Kasibhatla, P. S., and Arellano Jr., A. F.: Interannual variability in global biomass burning emissions from 1997 to 2004, Atmos. Chem. Phys., 6, 3423-3441, 2006,

http://www.atmos-chem-phys.net/6/3423/2006/.

Van Wagner, C. E.: Development and structure of the Canadian forest fire weather index system, Ottawa, ON, Canadian Forestry Service Technical Report 35, 1987.

Wesley, M. L.: Parameterization of surface resistance to gaseous dry deposition in regional numerical models, Atmos. Environ., 16, 1293-1304, 1989.

Wild, O., Zhu, X., and Prather, M. J.: Fast-j: Accurate simulation of in- and below-cloud photolysis in tropospheric chemical models, J. Atmos. Chem., 37(3), 245-282, 2000.

Wotawa, G. and Trainer, M.: The influence of Canadian forest fires on pollutant concentrations in the United States, Science, 288, 324-328, 2000.

Zhang, G. J. and McFarlane, N. A.: Sensitivity of climate simulations to the parameterization of cumulus convection in the canadian climate center general-circulation model, Atmos.-Ocean., 33(3), 407-446, 1995. 